\title{
The Potential for Reducing Energy Utilization in the Refining Industry
}

Energy Systems Division Argonne National Laboratory

Operated by The University of Chicago, under Contract W-31-109-Eng-38, for the United States Department of Energy 


\section{Argonne National Laboratory}

Argonne National Laboratory, with facilities in the states of Illinois and Idaho, is owned by the United States Government, and operated by the University of Chicago under the provisions of a contract with the Department of Energy.

This technical memo is a product of Argonne's Energy Systems (ES) Division. For information on the division's scientific and engineering activities, contact:

Director, Energy Systems Division

Argonne National Laboratory

Argonne, Illinois 60439-4815

Telephone (630) 252-3724

Presented in this technical memo are preliminary results of ongoing work or work that is more limited in scope and depth than that described in formal reports issued by the ES Division.

Publishing support services were provided by Argonne's Information and Publishing Division (for more information, see IPD's home page: http://www.ipd.anl.gov/).

\section{Disclaimer}

This report was prepared as an account of work sponsored by an agency of the United States Government. Neither the United States Government nor any agency thereof, nor The University of Chicago, nor any of their employees or officers, makes any warranty, express or implied, or assumes any legal liability or responsibility for the accuracy, completeness, or usefulness of any information, apparatus, product, or process disclosed, or represents that its use would not infringe privately owned rights. Reference herein to any specific commercial product, process, or service by trade name, trademark, manufacturer, or otherwise does not necessarily constitute or imply its endorsement, recommendation, or favoring by the United States Government or any agency thereof. The views and opinions of document authors expressed herein do not necessarily state or reflect those of the United States Government or any agency thereof, Argonne National Laboratory, or The University of Chicago. 


\section{The Potential for Reducing Energy Utilization in the Refining Industry}

by Michael Petrick

Energy Systems Division,

Argonne National Laboratory, 9700 South Cass Avenue, Argonne, Illinois 60439

and

Joan Pellegrino

Energetics, Inc.

Columbia, Maryland 21044

Work sponsored by U.S. Department of Energy,

Office of Energy Efficiency and Renewable Energy,

Office of Industrial Technologies 
This report is printed on recycled paper. 


\section{Contents}

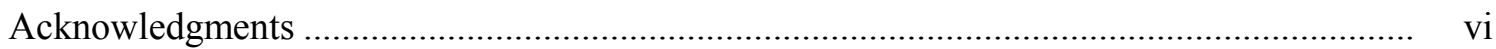

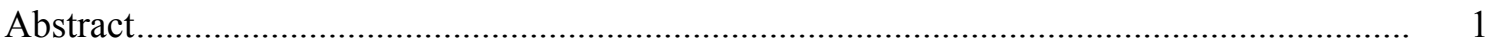

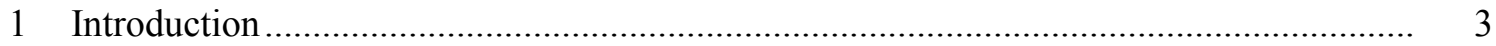

1.1 Energy Use in Refining and Carbon Emissions ..................................................... 3

1.2 Potential for Achieving Future Reductions in Energy Utilization and Greenhouse Gas Emissions ........................................................................... 4

1.3 The Motivation to Reduce Energy Use in Refining................................................ 7

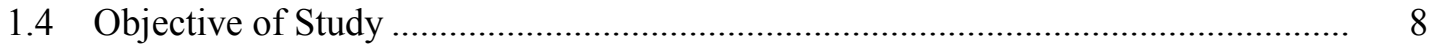

1.4.1 Study Scope and Limitations .................................................................... 8

1.4.2 Report Organization ..................................................................................... 9

2 Near-Term Opportunities for Improving Refinery Efficiency .................................. 10

2.1 Monitoring Overall Energy Performance ....................................................... 10

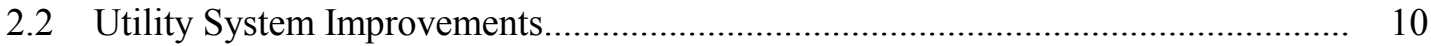

2.2.1 Cooling Water System.......................................................................... 10

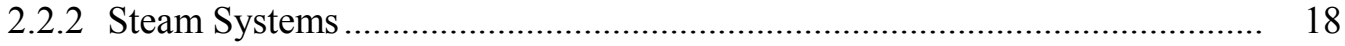

2.2.3 Fuel-Gas System.................................................................................. 19

3 Mid-Term Opportunities for Improving Refinery Efficiency ...................................... 20

3.1 Combustion Efficiency Improvements in Fired Heaters/Boilers ........................... 20

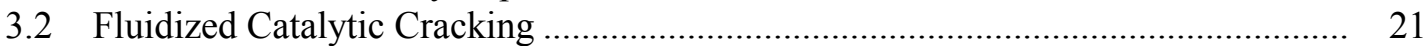

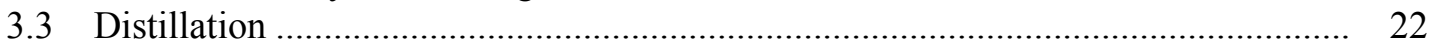

3.4 Heat Integration and Fouling Mitigation ….................................................. 23

3.5 Coke/Residue Gasification for $\mathrm{Co}$ - and Trigeneration $/ \mathrm{H}_{2}$ Production .................... 25

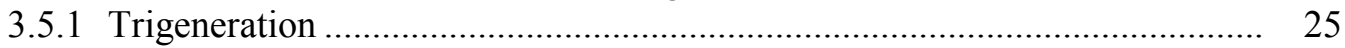

3.5.2 Impact on Energy-Use Efficiency........................................................ 26

3.6 Solid Catalyst Alkylation Technology .............................................................. 27

4 Long-Term Opportunities Requiring Further R\&D .................................................... 29

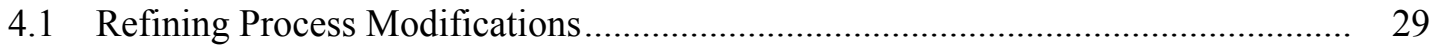

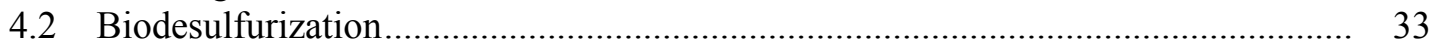

4.3 Development of Improved Catalysts............................................................. 34

5 Showcase Demonstration Program for Improving Refinery Efficiency .......................... 36 


\section{Contents (Cont.)}

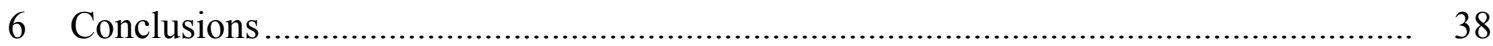

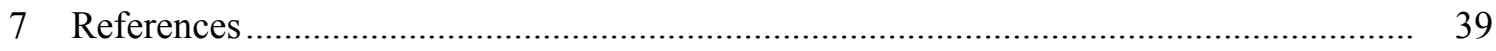

\section{Figures}

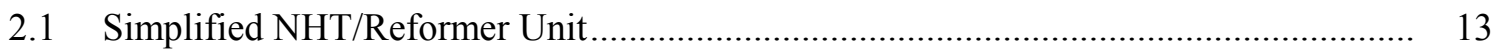

2.2 Simplified WHAARP Process Flow Diagram ........................................................ 13

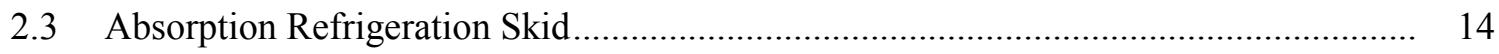

2.4 Process Diagram for Atmospheric Crude Distillation Using Ambient Condenser Water/CAAPS Simulation .................................................... 16

2.5 Process Diagram for Atmospheric Crude Distillation Using Chilled Condenser Water/CAAPS Simulation ............................................................ 16

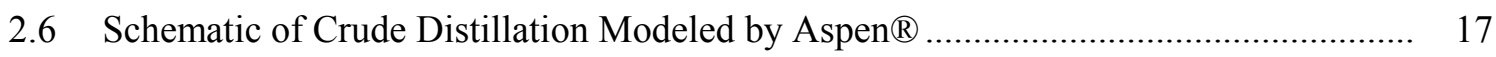

4.1 Refinery Using Atmospheric/Vacuum Distillation and Delayed Coking to Upgrade Crude....................................................................... 31

4.2 Refinery Using Fluidized-Bed Cracking to Upgrade Heavy Crude.............................. 31

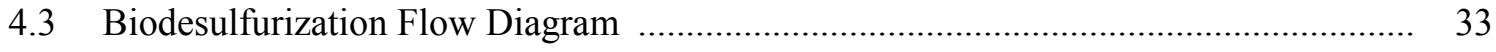

5.1 Projected Energy Intensity for the Denver Refinery ............................................ 37

\section{Tables}

1.1 Carbon Emissions from Combustion of Fossil Fuels in Petroleum

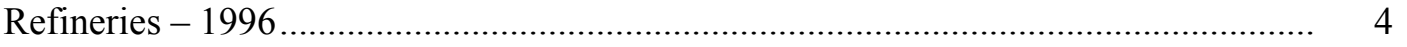

1.2 Estimated Carbon Emissions from Selected Refining Processes .................................. 6

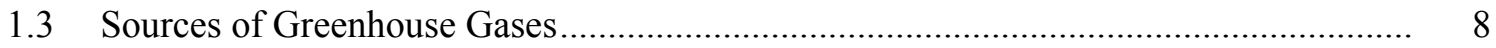

2.1 Sources of Waste Heat in the Refinery Complex ................................................. 11 


\section{Tables (Cont.)}

2.2 Estimated Reduction in Energy Requirements and Carbon Emissions from Utilization of Waste Heat Chillers on Atmospheric Distillation

2.3 Estimated Reduction in Energy Requirements and Carbon Emissions from Utilization of Waste Heat Chillers on Vacuum Distillation Columns

3.1 Potential Carbon Emission Reductions from Improved Combustion Efficiency

3.2 Reduction in Energy Use and Carbon Emissions Resulting from Increased Yields from Optimized FCC

3.3 Potential Carbon Emission Reductions from Improved Distillation Processes

3.4 Reduction of Energy Requirements and Carbon Emissions and Reduction in Fouling in Crude Preheat Train

3.5 Energy Savings and Carbon Reductions from Adoption of Cogeneration in Refineries

3.6 Potential Energy and Carbon Emission Reductions from Replacement of Sulfuric Acid with Solid Acid Alkylation.

4.1 Estimates of Fuels and Utility Comparison for Crude Distillation vs. Thermal Cracking

4.2 Reduction in Carbon Emissions and Energy Use: Thermal Cracking vs. Crude Distillation.

4.3 Comparison of Energy Requirements and Carbon Emissions: HDS vs. BDS

5.1 Reduced Emissions from Implementation of the Master Plan on Refining. 37

6.1 Reduction in Energy Use and Carbon Emissions Possible through Adoption of Selected Advanced Technologies in Petroleum Refining. 


\section{Acknowledgments}

This study, which evolved over several years, was supported by the U.S. Department of Energy, Office of Energy Efficiency and Renewable Energy, Office of Industrial Technologies. During the study, the authors had the opportunity to interact with a number of colleagues at Argonne National Laboratory and with current and former members of the refining industry, namely, C.B. Panchal, G. Boyd, J. Robertson, R. Bertolacini, M. Pacheco, and P. Cuneo. Their comments, suggestions, and feedback provided important input into the study. The authors would also like to thank N. Brockmeier, who helped carry out some of the more complex analyses, and P. Brice, who provided an insightful critique of the final draft. Finally, the authors are indebted to E. Hartig for her patience and support in preparing the manuscript. 


\section{Abstract}

The petroleum refining industry is one of the largest users of fossil fuels in the industrial sector and, hence, a major source of $\mathrm{CO}_{2}$ emissions. In the United States, the processing of crude oil into transportation fuels, petrochemical feedstocks, and other products generates $\approx 13 \%$ of the $\mathrm{CO}_{2}$ emissions emanating from the country's industrial sector. The $\mathrm{CO}_{2}$ emissions result from the combustion of a variety of fossil fuels in process heaters and boilers, including, for example, refinery gas, residual fuel, coke, and natural gas. Energy use and its utilization efficiency in a refinery are dictated by (1) the quality of the crude slate processed, (2) product slate produced, (3) refinery configuration (complexity and size), (4) environmental dictates, and (5) cost and availability of fuels and energy. $\mathrm{CO}_{2}$ emissions from refining can be most readily reduced by increasing process and/or combustion efficiency and by maximum use of natural and refinery gases. As a result, the opportunities to generate substantial improvements in energy use efficiency and, thus, reductions in $\mathrm{CO}_{2}$ emissions will vary from refinery to refinery.

A study was undertaken to identify and assess carbon-reduction technologies and/or process operating improvements that could be implemented in refining. They are broken down into (1) near-term: straightforward improvement opportunities; (2) mid-term: process equipment modifications; and (3) longerrange technology opportunities that would have major impacts but require further R\&D. A number of the technologies were subjected to preliminary quantitative analysis, and reductions in $\mathrm{CO}_{2}$ emissions that would accrue from their implementation were estimated. Ten technologies were shown to be especially promising; potential $\mathrm{CO}_{2}$ reductions from the implementation of the individual technologies ranged from 1 to $20 \%$ of current emission levels. The results from the individual technology assessment studies were underscored and placed in perspective through a detailed study of an operating refinery that was undertaken to define specific cost-effective efficiency improvement projects to increase energy utilization efficiency and reduce emissions. Development of a four-phase program is described.

The studies indicate that there are a number of cost-effective technologies that can be implemented to achieve substantial reductions in $\mathrm{CO}_{2}$ emissions in petroleum refining. In the near term, significant opportunities exist that, if they can be justified from either an economic and/or environmental stewardship vantage point, could lead to energy use and $\mathrm{CO}_{2}$ reduction of 3-7\%. In the midto long term, the potential reductions that may be achievable by adopting selected advanced technologies appear to be substantial. In light of the many factors involved, a target reduction of 15-20\% in energy use and $\mathrm{CO}_{2}$ emissions 
from the refining sector does not appear to be unreasonable, assuming a favorable investment climate. This projection must immediately be tempered by the probability that more stringent regulations will likely be imposed on the industry to reduce sulfur levels to very low levels in the gasoline and diesel fuels that will be used by the next generation of advanced, more efficient vehicles introduced into the marketplace. Energy usage and achievable reductions in carbon emissions could suffer significantly. 


\section{Section 1 Introduction}

\subsection{Energy Use in Refining and Carbon Emissions}

Petroleum refining is the most energy-intensive industry in the United States. The industry accounted for $\approx 7 \%$ of total energy consumed in the United States in 1994 [1]. Historically, the amount of process energy used, the types of fuels consumed, and the efficiency of their utilization in refining crude oil to supply the U.S. marketplace have depended upon many factors and, not surprisingly, have therefore varied over time. Examples of key factors are (1) the quality of crude slate processed, (2) the cost and availability of fuel and energy, (3) product slate produced to meet market demand, (4) refinery configuration (complexity and size), (5) capital availability, and (6) environmental dictates (product specifications). Over the past three decades, these factors have forced the refining industry to change dramatically; these changes, in turn, have affected energy utilization.

From 1969 to 1974, energy used per barrel processed declined at a rate of $0.8 \% / y r$ [2]. In 1975, energy use was about 3.2 Quads. The oil supply disruptions and the high price of oil in the 1970s motivated the industry to continue efforts to minimize energy usage and, hence, energy intensity. By 1983, energy utilization had dropped to 2.6 Quads [3]. Since 1985, refineries have become more complex, and plant size has increased. The specifications of gasoline are tending to be set by environmental regulations. The quality of the crude slate processed has declined. The deteriorating quality of crude and the market pressures to produce more "white products" per barrel processed motivated refiners to add more advanced processing capability, thus increasing refining complexity and energy utilization per unit of output. By 1990, energy usage had again risen to a level of about 3.0 Quads. Since 1990, energy usage has remained relatively constant; projected 1996 utilization is 3.258 Quads [1]. The most recent trend in the industry - mergers and consolidations - has resulted in the closure of a number of smaller, inefficient refineries and, thus, in an increase in the average size. Since the larger plants are generally more efficient, this trend will help reduce and/or stabilize energy consumption in this industry.

An estimate of greenhouse gas emissions generated from the combustion of fossil fuels in petroleum refineries is provided in Table 1.1. As indicated in 1996, the U.S. refining industry generated an estimated 60.4 MMTCE (million metric tons of carbon equivalent) of greenhouse gases, which is $\approx 12 \%$ of the total emanating from the industrial sector; this amount corresponds to $221 \mathrm{MMT}$ (million metric tons) of $\mathrm{CO}_{2}$. The $\mathrm{CO}_{2}$ was generated from the combustion of a variety of fuels to produce process heat, steam, and electrical energy. These emissions were calculated on the basis of energy consumption reported for 1996 [4] and by using carbon coefficient factors developed for individual fuel types. The amount of carbon released when fossil fuels are burned depends on the carbon content, density, and gross heat of combustion for

* 1 Quad $\equiv 10^{15}$ Btu. 
the particular fuel. For example, the carbon coefficient for refinery gas was estimated by assuming that the gas consists of a mix of hydrocarbons (principally methane, ethane, ethylene, normal butane, butylene, propane, and propylene) plus hydrogen. The carbon coefficients and energy consumption data used in this study are provided in Table 1.1. A detailed explanation of how carbon coefficients were derived can be found in Reference 5 .

Table 1.1 Carbon Emissions from Combustion of Fossil Fuels in Petroleum Refineries - 1996

\begin{tabular}{|c|c|c|c|c|}
\hline Fuel Type & $\begin{array}{c}\text { Carbon } \\
\text { Coefficient } \\
\text { (lb CO} / \mathrm{M} \mathrm{Btu})\end{array}$ & $\begin{array}{l}1996 \text { Energy Use in } \\
\text { Petroleum Refining } \\
\qquad\left(10^{12} \mathrm{Btu}\right)\end{array}$ & $\begin{array}{l}\text { Carbon } \\
\text { Emissions } \\
\text { (MMTCE) }\end{array}$ & $\begin{array}{c}\mathrm{CO}_{2} \\
\text { Emissions } \\
\left(10^{3} \text { tons }\right)\end{array}$ \\
\hline Crude Oil & 163.9 & 0.01 & 0.000203 & 0.8195 \\
\hline $\mathrm{LPG}^{\mathrm{a}}$ & 138.6 & 26.7 & 0.458103 & 1850.31 \\
\hline Distillate Fuel & 161.2 & 4.3 & 0.085807 & 346.58 \\
\hline Residual Fuel & 173.6 & 54.9 & 1.179807 & 4765.32 \\
\hline Refinery Gas & 141.5 & 1,435 & 25.13605 & 101526.25 \\
\hline Petroleum/Catalyst Coke & 224.98 & 524.0 & 14.59365 & 58944.76 \\
\hline Natural Gas & 116.9 & 797.6 & 11.5422 & 46619.72 \\
\hline Coal & 207.5 & 3.1 & 0.079 & 321.625 \\
\hline Purchased Electricity & 133.4 & 337.0 & 5.57 & 22477.9 \\
\hline Purchased Steam & 207.5 & 40.1 & 1.03 & 4160.375 \\
\hline Unfinished Oils & 163.3 & 35.7 & 0.727 & 2914.905 \\
\hline TOTALS & & 3258.41 & 60.39 & 243928.6 \\
\hline
\end{tabular}

\footnotetext{
a Liquid propane gas.
}

\subsection{Potential for Achieving Future Reductions in Energy Utilization and Greenhouse Gas Emissions}

The potential for reducing energy utilization and $\mathrm{CO}_{2}$ and other greenhouse gas emissions will continue to be influenced largely by the various factors cited above. The 1997 Energy Information Administration outlook, taking into account market and crude supply factors, projects that the energy usage in the industry can be expected to increase by $0.3 \% / \mathrm{yr}$ [6]. To reverse this trend (and thus to achieve major reductions in the critical greenhouse gas, $\mathrm{CO}_{2}$, as called for in the Kyoto Agreement), the energy utilization efficiency of the key (highest energy consuming) refining processes and energy supply systems must be improved.

The most viable approach to reducing energy use and carbon emissions in refining can be surmised from considering the following simple global carbon balance equations, as suggested in [7]:

$$
\text { Net } \mathrm{C}=[\mathrm{GDP} \times(\mathrm{E} / \mathrm{GDP}) \times(\mathrm{Cg} / \mathrm{E})]-\mathrm{S}
$$


where

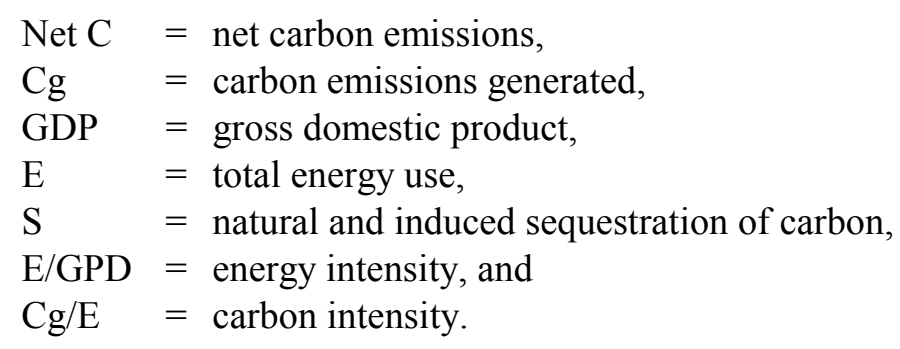

To reduce carbon emissions from refining under the assumption of a growing economy (increasing product output), both the energy intensity and carbon intensity of the refining process must decrease, or the sequestration of carbon must be increased. The development of economically viable sequestration technologies is likely to be a long-term option; therefore, the emphasis must be on reducing the carbon intensity and energy intensity of the refining process. The energy intensity reflects the energy used in the various refining processes to convert a barrel of feedstock into product, and the carbon intensity can be related to the types of fossil fuels used and the efficiency of their utilization.

The desired efficiency improvements can be achieved via the adoption of various steps, such as (1) introducing more efficient equipment, (2) reducing process activation energies and increasing product yields (through improved catalysts), (3) improving equipment integration to recover more heat, and (4) adopting improved process controls.

A number of studies have identified the key processes that must be addressed and processes and technology innovations/modifications that have the potential to substantially reduce energy consumption $[2,6]$. The most energy-intensive processes in a refinery - considering both specific energy use for the process stream and percentage of total energy use in the refining process - are listed in Table 1.2.

Note that fluidized catalytic cracking is not listed in Table 1.2, even though it is a major user of energy ( $\approx 20-30 \%$ of total energy consumed in refineries). Fluidized catalytic cracking (FCC) derives its energy from the combustion of carbon deposited on the catalyst in the regenerator. The carbon is generated in the riser reactor as the feedstock is cracked into smaller molecules. The FCC unit thus consumes a portion of the feedstocks (deposited carbon) as fuels. The unit ideally is run in a heat-balanced mode, where the carbon lay down is adjusted to meet energy needs in the riser reactor. In reality, the FCC unit tends to be an exporter of energy within the refinery. The FCC unit was therefore not included in the table because it operates in a near heatbalanced mode. Overall refinery energy consumption can be reduced significantly, however, by increasing product yields per unit of feedstock processed in the FCC unit. This concept is discussed in Sections 3.2 and 4.3. 
Table 1.2 Estimated Carbon Emissions from Selected Refining

Processes

\begin{tabular}{|c|c|c|c|}
\hline Process & $\begin{array}{c}\text { Average } \\
\text { Energy Use }^{a} \\
\left(10^{3} \mathrm{Btu} / \mathrm{bbl}\right)\end{array}$ & $\begin{array}{l}1997 \text { Capacity } \\
\left.\text { (10 } 10^{6} \mathrm{bbl} / \mathrm{cday}\right)\end{array}$ & $\begin{array}{l}\text { Annual Carbon } \\
\text { Emissions } \\
\text { (MMTCE) }\end{array}$ \\
\hline Atmospheric Distillation $^{\mathrm{b}}$ & 113.8 & 15.45 & 11.87 \\
\hline Vacuum Distillation & 91.5 & 7.15 & 4.43 \\
\hline Delayed Coking & 166 & 1.671 & 2.07 \\
\hline Catalytic Hydrocracking & $240(71.8)^{\mathrm{C}}$ & 1.3 & 1.31 \\
\hline Catalytic Hydrotreating & $120(31.1)^{c}$ & 10.7 & 5.98 \\
\hline Catalytic Reforming & $284(15.4)^{c}$ & 3.6 & 6.55 \\
\hline
\end{tabular}

a Includes losses from generation and transmission of electricity (electricity conversion factor of $0.500 \mathrm{Btu} / \mathrm{kWh}$ ). Does not include $\mathrm{H}_{2}$ or $\mathrm{O}_{2}$.

b Includes energy consumed for desalting of crude.

c Net steam export is shown in parentheses.

Although studies $[2,6]$ cite numerous options that could improve the energy efficiency utilization of the processes, the issues of the economic viability and risk involved in retrofitting these modifications/components into the spectrum of plant configurations that exist in the industry today were not addressed. It is clear that the cost/benefit ratios for incorporating the candidate technologies/processes are highly site-specific and are very sensitive to future market and governmental dictates.

An important parallel issue, and a major potential barrier to making improvements/ modifications to improve energy utilization, is the fact that refiners are also being forced to modify refinery processes/configurations to be able to refine crudes of lower quality and to comply with environmental dictates. Such changes can readily have undesirable impacts on energy usage and/or emissions. A clear example of this situation is given in [8], which discusses a major $\$ 2.2$ billion revamp of a $400,000-b b 1 /$ day refinery that is under way to accommodate expected changes in crude supply and to meet current and future product volume and quality demands. The refinery crude supply is expected to shift to a higher proportion of Middle East crude, increasing the sulfur intake (to the refinery) by about $45 \%$. The changes in refinery output as a result of the extensive modifications are (1) the white product make will increase by $10 \%$ and (2) fuel oil production will decrease by $40 \%$.

With regard to environmental emissions, $\mathrm{SO}_{2}$ and $\mathrm{NO}_{\mathrm{x}}$ emissions are expected to be reduced by 35 and $45 \%$, respectively, primarily because of reduced residual oil firing; also, particulate matter emissions will be cut in half. However, $\mathrm{CO}_{2}$ emissions from the refining site are expected to rise substantially - by about $22 \%$ - because of the use of greater amounts of hydrogen in the refining process. The global emission level of $\mathrm{CO}_{2}$ resulting from the changes in refining and the combustion of the products produced is, however, expected to be lower than the $22 \%$ because of the higher hydrogen content of the refinery's products. The projection, in fact, is for the net global level to remain essentially constant. In general, however, the net change in global $\mathrm{CO}_{2}$ emissions resulting from such modifications in refining and product slates will depend upon the 
thermal and chemical efficiency of the hydrotreater and hydrogen units, the actual product slate produced, and the combustion efficiency of the transportation-vehicle engines burning the fuel.

The above example serves to underscore the complexity and uncertainties associated with generating projections relative to levels of energy-efficiency improvements and the magnitude of emission reductions that can be achieved. Nevertheless, it seems clear that there are a number of steps and/or technology options that, if implemented, could reduce energy usage and help reduce emissions.

\subsection{The Motivation to Reduce Energy Use in Refining}

The industry has traditionally pursued opportunities to reduce energy use when motivated by market and economic considerations (as discussed in Section 1.1). Recently, however, a major new issue has evolved that is providing an additional impetus to consider opportunities for reducing energy use: the issue of global climate change.

Worldwide, there is growing concern that the $\mathrm{CO}_{2}$ concentration in the atmosphere is rising and that the Earth's surface temperature is increasing. The concern reflects the mounting consensus that (1) there appears to be a causal relationship among $\mathrm{CO}_{2}$ (and other greenhouse gases), atmospheric concentrations, and surface temperatures and (2) the small fraction of anthropogenic (man-made) greenhouse gases resulting from human activity (e.g., combustion of fossil fuels, deforestation, etc.) can upset the balance between the much greater natural flows and thus cause global climate change.

Greenhouse gases trap heat in the atmosphere; they are transparent to solar radiation that enters the Earth's atmosphere, but they strongly absorb the infrared thermal radiation emitted by the Earth. The most common man-made and natural sources of greenhouse gases are listed in Table 1.3. Historical evidence suggests that the Earth's climate system adapts relatively well to small and/or slow changes in the concentration of atmospheric greenhouse gases. However, rapid changes in the concentration of anthropogenic (man-made) greenhouse gases may constitute a major force for climate change. An increase in the average temperature of the Earth could have serious implications for global climates. Larger environmental disruptions may result from climatic disequilibrium caused by a combination of climatic changes (i.e., increasing greenhouse gases, albedo changes, and stratospheric ozone depletion). As the concentration of greenhouse gases increases, the rate of change in global climate patterns may accelerate and limit the ability of ecosystems to adapt to these changes.

There is little doubt within the scientific community that global warming (and other changes in global climates) could have significant impacts on the world as we know it. However, there is no scientific consensus that global warming is actually occurring at present. Clearly, more extensive research over extended periods will be required before definitive answers emerge. In the interim, prudence dictates that every segment of our society that is a major contributor of $\mathrm{CO}_{2}$ and other greenhouse gases to the ecosystem make every effort to control and reduce such emissions. This view is reflected in evolving public policy $[9,10]$. 
Table 1.3 Sources of Greenhouse Gases

\begin{tabular}{|c|c|c|c|c|}
\hline Greenhouse Gas & Anthropogenic Sources & $\begin{array}{c}\text { Global } \\
\text { Emissions of } \\
\text { Anthropogenic } \\
\text { Sources } \\
\text { (MMTCE) }\end{array}$ & Natural Sources & $\begin{array}{l}\text { Global } \\
\text { Natural } \\
\text { Emissions } \\
\text { (MMTCE) }\end{array}$ \\
\hline $\begin{array}{l}\text { Carbon dioxide } \\
\left(\mathrm{CO}_{2}\right)\end{array}$ & $\begin{array}{l}\text { Combustion of fossil fuels; } \\
\text { calcination of limestone, soda ash } \\
\text { manufacture and use; aluminum } \\
\text { production }\end{array}$ & 7,100 & Biological processes & 150,000 \\
\hline $\begin{array}{l}\text { Nitrous oxide } \\
\left(\mathrm{NO}, \mathrm{NO}_{2}\right)\end{array}$ & $\begin{array}{l}\text { Combustion of fossil fuels; nitrogen } \\
\text { fertilizers; manufacture of adipic and } \\
\text { nitric acid }\end{array}$ & $4-8$ & $\begin{array}{l}\text { Biogenic processes } \\
\text { in soil; lightning }\end{array}$ & $6-12$ \\
\hline Methane $\left(\mathrm{CH}_{4}\right)$ & $\begin{array}{l}\text { Coal mining; oil refining; gas drilling } \\
\text { and transmission; chemical, iron, } \\
\text { and steel production }\end{array}$ & $300-450$ & $\begin{array}{l}\text { Aerobic decay of } \\
\text { vegetation; termites } \\
\text { (tropics); ruminant } \\
\text { animals; rice fields }\end{array}$ & $110-210$ \\
\hline $\begin{array}{l}\text { Chlorofluorocarbons } \\
\text { (CFC-11, CFC-12, } \\
\text { CFC-113) }\end{array}$ & $\begin{array}{l}\text { Release of engineered chemical } \\
\text { refrigerants and solvents }\end{array}$ & $\begin{array}{l}0.2 \\
\text { (United States } \\
\text { only) }\end{array}$ & No natural source & - \\
\hline
\end{tabular}

\subsection{Objective of Study}

Because the refining industry is a significant contributor to $\mathrm{CO}_{2}$ emissions in the United States, the industry will likely be called upon to do its share and provide the environmental stewardship that will lead to lower $\mathrm{CO}_{2}$ and other greenhouse gas emissions. A two-part study was undertaken to identify and qualify, when possible, key opportunities that the refining industry could pursue to reduce energy use and, hence, greenhouse gas emissions.

An initial study was undertaken to develop a preliminary assessment of a broad range of opportunities that are available to the refining industry to achieve substantive reductions in energy used. The information from this study was used to provide input into a more comprehensive study of the $\mathrm{CO}_{2}$ problem by five national laboratories [6]. Recently, a follow-on study was completed that focused on exploring some of the most promising opportunities in more detail by conducting additional analyses to provide quantitative projections of energy use reductions. The results from both studies are summarized in this report.

\subsubsection{Study Scope and Limitations}

This report focuses on those technologies or opportunities that appear to have the greatest potential for improving energy efficiency utilization and, hence, reducing $\mathrm{CO}_{2}$ emissions from refineries. Where possible, the potentials are illustrated by projections of the reductions that may be achieved by 2010 and beyond. The specific examples and ideas presented have been subjected to widely varying degrees of evaluation and/or analysis. Some are based on assumed performance levels derived from limited data; others reflect the knowledge and experience of 
individuals who have worked in the industry for extended periods. Still others have been evaluated through development of zero- to first-order computer simulations of process modifications to develop quantitative estimates of performance improvements. Many of the examples cited undoubtedly have already been adopted and/or incorporated into the most efficient refineries operating today. Nevertheless, the results indicate that there appear to be substantial additional opportunities for improving the energy utilization efficiency. The projections are based on data/information available at this time and assumed penetration scenarios for each technology. Many of the projections are "guesstimates," at best, and they should be treated as such.

\subsubsection{Report Organization}

Examples of process, technology, and operating improvements that could potentially generate substantial improvements in energy utilization efficiency are broken down into three categories, namely: (1) near-term, straightforward improvement opportunities; (2) mid-term process/equipment modifications; and (3) long-range opportunities requiring further R\&D. Section 5 documents the results of a study of a showcase demonstration program for improving refinery efficiency. The conclusions are presented in Section 6. 


\section{Section 2 \\ Near-Term Opportunities for Improving Refinery Efficiency}

A number of relatively straightforward equipment, maintenance, and operational changes can be made to improve the overall energy-use efficiency in refineries. Such improvements generally can be expected to have longer paybacks than current industry standards and are therefore likely to be difficult to justify under current prevailing economic conditions (e.g., low refining profit margins, low fuel costs, limited availability of capital [from cash flow], management preoccupation with meeting environmental regulatory mandates, etc.). Nevertheless, with appropriate investment incentives, their implementation could produce substantial energy savings.

\subsection{Monitoring Overall Energy Performance}

Every refinery could promote energy efficiency stewardship by rigorously pursuing a program to monitor equipment, process, and overall refinery energy performance to identify (as early as possible) deviations from nominal (design) operating conditions and initiating corrective actions. Measured usage of energy for key equipment and systems can be compared with allocated energy values based on efficient, established (allocated) performance criteria and/or targets. Estimates of energy savings that can be realized through such action range from 1 to $4 \%$ $[11,12]$.

\subsection{Utility System Improvements}

The principal utility systems in a refinery - the cooling, steam, power, and fuel-gas systems - are integrated with virtually every major refinery process subsystem. Relatively speaking, these systems, in general, have not received and do not receive the same level of attention as the critical refining process subsystems since they basically support these systems. Utility systems can, however, significantly impact overall refinery operations. The potential for achieving energy savings and $\mathrm{CO}_{2}$ reductions by improving their function and operation is substantial.

\subsubsection{Cooling Water System}

Perhaps the most overlooked opportunity for saving energy lies in generating improvements in the cooling water system and/or providing supplemental low-temperature cooling. Lower temperature water can substantially lower the light ends emanating from towers and, in turn, decrease the reboiler duty (for a constant separation). Similarly, lowering the temperature of operation of absorbers would reduce the amount of light hydrocarbons lost to fuel gas and increase the recovery of valuable products. Cooling the feed to the suction of the compressor can knock out additional liquid (product) and reduce energy consumption; lowering the suction and intercooler temperatures will also improve efficiency, even if no additional liquid is removed. The availability of enhanced cooling would yield numerous other opportunities for saving energy. 
The traditional approach to lower cooling water temperatures is to revamp cooling towers by using modern fill material to get a closer approach to the wet bulb temperature. Specific limits are encountered with this approach that vary with the ambient conditions. Additional/enhanced cooling capability, however, can be achieved by judicious use of a new generation of waste-heatdriven absorption chiller systems to either further reduce the temperature of cooling water streams or to cool process streams directly. Such systems also provide an opportunity to utilize low-grade heat that is in excess in various parts of the refinery. Table 2.1 provides examples of typical stack gas waste heat streams from various refinery process units that could be used to drive efficient, advanced absorption refrigeration units to provide enhanced cooling. As indicated, these streams contain approximately one-half of a Quad $\left(10^{15} \mathrm{Btu}\right)$. Examples of the beneficial use of enhanced cooling are described in the following sections.

Table 2.1 Sources of Waste Heat in the Refinery Complex (based on 1997 operating U.S. crude capacity, 93\% utilization)

\begin{tabular}{|lcccc|}
\hline $\begin{array}{c}\text { Heater and Boiler } \\
\text { Stack Gas Source }\end{array}$ & $\begin{array}{c}\text { Temperature } \\
\text { Range of Stack } \\
\text { Gas }\left({ }^{\circ} \mathbf{F}\right)\end{array}$ & $\begin{array}{c}\text { Heat Content } \\
\left(\mathbf{1 0 ^ { 3 }} \text { Btu/bbl of }\right. \\
\text { crude processed) }\end{array}$ & $\begin{array}{c}\text { Annual Energy } \\
\text { Value }\left(\mathbf{1 0}^{\mathbf{1 2}}\right. \\
\text { Btu) }\end{array}$ & $\begin{array}{c}\text { \% of Total } \\
\text { Waste Heat }\end{array}$ \\
\hline Atmospheric Distillation & $700-900$ & 13.8 & 74.4 & 15.3 \\
Vacuum Distillation & $700-900$ & 3.7 & 19.7 & 4.1 \\
Fluidized Catalytic Cracking & $800-900$ & 8.5 & 46.0 & 9.5 \\
Catalytic Hydrocracking & $700-900$ & 3.0 & 16.9 & 3.5 \\
Catalytic Reforming & $700-950$ & 13.1 & 70.6 & 14.5 \\
Cokers & $800-1000$ & 1.2 & 6.6 & 1.4 \\
Alkylation & $650-700$ & 6.3 & 33.8 & 7.0 \\
Visbreaking & $700-800$ & 2.4 & 12.6 & 2.6 \\
Hydrotreating & $700-900$ & 3.4 & 34.7 & 7.0 \\
Lube Oil Manufacture & $700-900$ & 2.0 & 10.5 & 2.2 \\
Asphalt Processing & $550-600$ & 0.8 & 4.4 & 0.9 \\
Electricity Generation & $550-600$ & 2.1 & 11.7 & 2.4 \\
Central Boilers & $400-500$ & 26.7 & 143.7 & 29.6 \\
TOTAL & & 87.0 & 485.6 & 100.0 \\
\hline
\end{tabular}

\subsubsection{Product Recovery/Wet Gas Compressor Debottlenecking}

The application of a waste-heat-driven ammonia absorption refrigeration plant (WHAARP) was recently demonstrated at a 30,000-bbl/day refinery of the (then) Colorado Refinery Company in Commerce City, Colorado. The installation of the unit was supported by a U.S. Department of Energy (DOE) grant from the ClimateWise Demonstration Program. The opportunity for utilization of the WHAARP evolved from a refinery energy audit that utilized mass integration and heat pinch analyses. The analyses indicated that the net gas and treat gas streams in the reformer unit contribute significantly to the loss of salable product to the fuel gas system. The majority of the product is lost during summer operation, a time during which the cooling of reformer reactor effluent decreases. 
A simplified block diagram of the reformer unit is shown in Figure 2.1; also shown are the locations for the waste heat tie in and the net/treat gas stream where the WHAARP is located. The unit, which is powered by the $290^{\circ} \mathrm{F}$ waste effluent stream from the reformer reactor, is designed to deliver 85 refrigeration tons $(\mathrm{RT})$ at $-31^{\circ} \mathrm{F}$ for cooling the net/treat gas and $180 \mathrm{RT}$ at $26^{\circ} \mathrm{F}$ for cooling the overhead wet gas stream. Cooling helps to debottleneck the compressors and the unsaturated light-cycle oil streams. A schematic of a WHAARP is shown in Figure 2.2. The absorption refrigeration unit of the system, which began operation in August 1997, is shown in Figure 2.3. The unit was designed with a coefficient of performance (COP) of 0.5. To extend the applicability of this technology by using low-temperature waste heat and to make the economics more favorable, several unique advanced concepts were developed and incorporated into the refrigeration system.

Approximately 65,000 barrels of liquid propane gas (LPG) that previously was flared or burned as fuel is recovered annually; as expected, the recovery rate varies considerably over time (i.e., it varies throughout the year in response to ambient temperature variations and loading of the reformer unit). Analysis of the liquid product stream has disclosed a higher percentage of heavier (i.e., $\mathrm{C}_{5}, \mathrm{C}_{6}{ }^{+}$), higher value products than originally estimated. The recovery of highgrade product translates into a reduction in $\mathrm{CO}_{2}$ emissions of $\approx 10,000$ tons/yr. The simple payback for this first-of-a-kind demonstration installation was $1.5 \mathrm{yr}$ [13].

\subsubsection{Application of Enhanced Cooling to Distillation Units}

Many unit operations in petroleum refining rely on distillation to upgrade heavy petroleum fractions and to upgrade intermediate petroleum fractions. For example, atmospheric and vacuum distillations are used to upgrade crude and topped crude, respectively. In addition, distillation is used to upgrade product streams from visbreakers, delayed and fluid cokers, catalytic crackers and hydrocrackers, catalytic reformers, hydrotreaters, etherification units, and isomerization units.

The reboiler duty on distillation units in U.S. refineries has been estimated at about 1 quadrillion Btu annually, which is over $35 \%$ of total refinery process energy consumption [14]. Reboiler energy requirements are usually met by steam that is produced by combustion of a variety of fuels, including natural gas, refinery fuel gas, fuel oils, petroleum coke, and sometimes heavy by-product or waste oils. Carbon emissions associated with combustion of fuels for this purpose are significant (over 15 MMTCE annually) and represent a large target of opportunity for potential reductions.

A particularly intriguing opportunity for reducing reboiler duty is to use chilled water to lower the temperature of the overhead condenser and, thus, lower the reflux ratio on the crude tower. The amount of heat needed for reboiling is directly related to the reflux ratio, as illustrated by the following equation:

$$
\mathrm{Qs}=\mathrm{Hv}(\mathrm{R}+1) \mathrm{D} \text {, }
$$




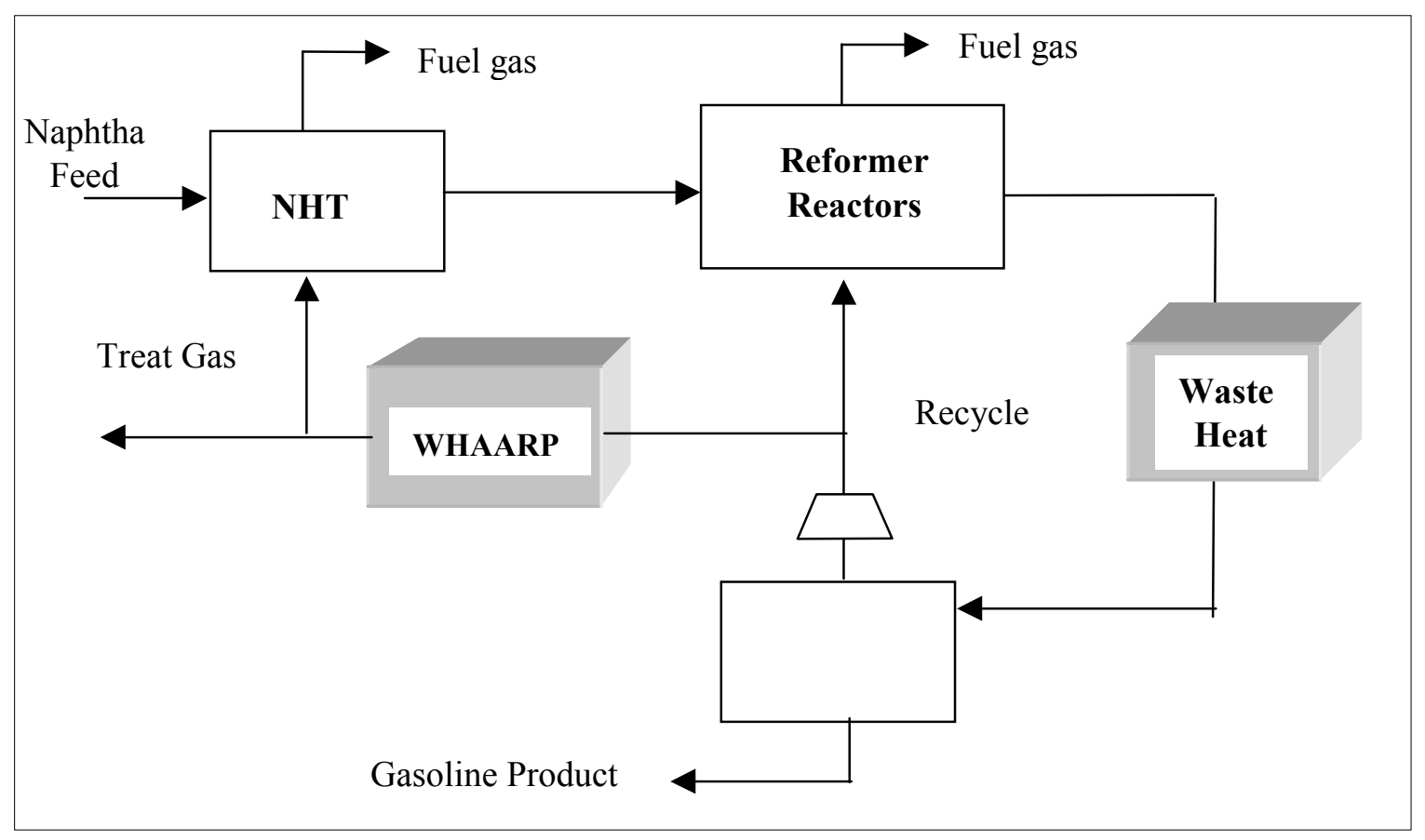

Figure 2.1 Simplified NHT/Reformer Unit

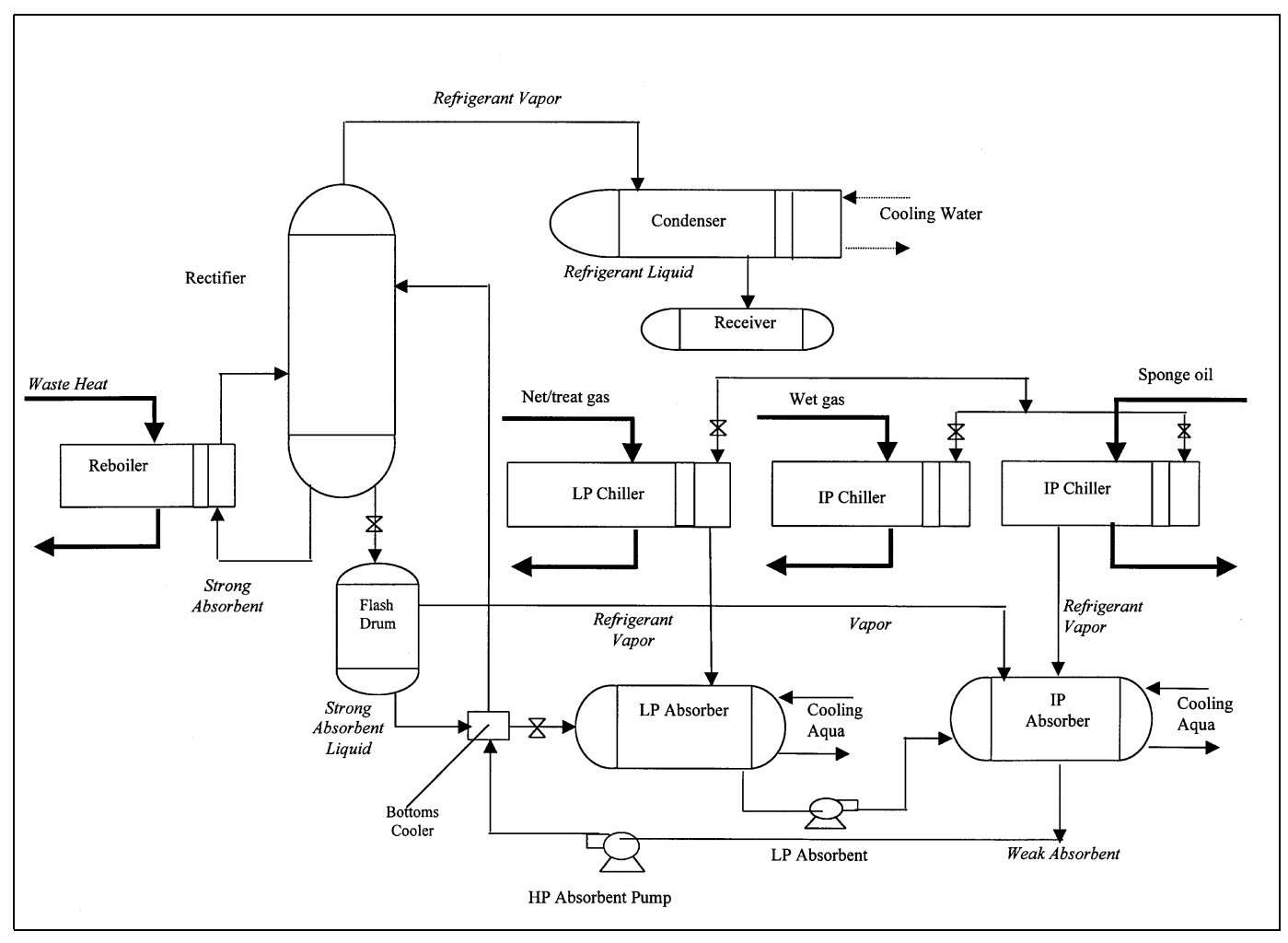

Figure 2.2 Simplified WHAARP Process Flow Diagram 


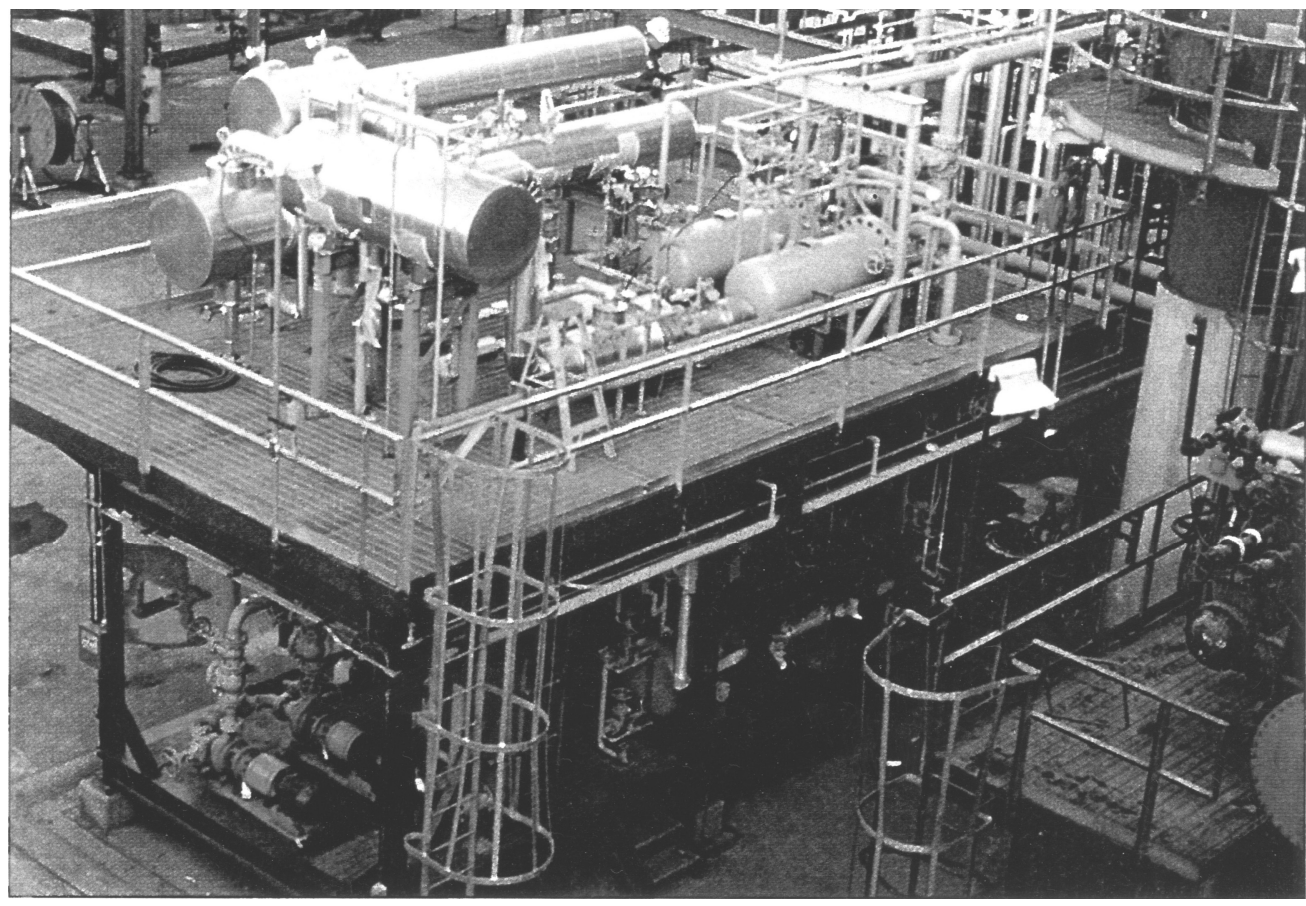

Figure 2.3 Absorption Refrigeration Skid

where

Qs = energy required for the reboiler,

$\mathrm{Hv}=$ heat of vaporization of the overhead product,

$\mathrm{R}=$ reflux ratio (liquid return to column/condensing overhead product), and

$\mathrm{D}=$ condensing overhead product.

Cooling water for overhead condensers in refineries is usually available at near-ambient conditions $\left(65-75^{\circ} \mathrm{F}\right)$, with a typical temperature rise through the condenser of about $20-25^{\circ} \mathrm{F}$. One energy-efficient means for providing cooling water at lower temperatures is to use waste heat in the refinery to run absorption chillers. Chilled water as low as $41^{\circ} \mathrm{F}$ can be supplied from absorption chillers, which is considerably colder than ambient cooling water and, therefore, can greatly increase heat removal capability. As indicated previously, waste heat is available from a number of sources in the refinery (see Table 2.1) and, thus, can be used to drive absorption chiller systems.

Several preliminary analyses of the crude distillation tower were made to gain perspective on the magnitude of the reduction in energy used that can be achieved with lower-temperature cooling water. The first analysis focused on using chilled water on the overhead condenser; the analysis was made by using a multicomponent distillation model [15]. This relatively simple model was developed as an instructional tool for chemical engineers and performs thermodynamic calculations (enthalpy, vapor-liquid equilibria) based on ideality. The model contains a properties database that can be modified to include user-defined properties. For this 
analysis, thermodynamic data were estimated from $\mathrm{K}$ values for a heavy crude (about ${ }^{\circ} \mathrm{API} 11$ ), assuming the fractions shown in Figure 2.4. The system chosen for modeling is a simple multicomponent distillation tower with an overhead condenser and reboiler. The tower is processing heavy crude at the rate of about $43,000 \mathrm{bbl} /$ day. To simplify the system for use with this model, the distillate streams are shown as a combined pseudoproduct from the overhead condenser. In reality, they would be taken from different positions in the tower.

Figure 2.4 illustrates conditions for the tower using nonchilled water at $75^{\circ} \mathrm{F}$ for the condenser. Net energy input in this situation is about 140.5 million Btu/h. Figure 2.5 illustrates conditions when chilled water is provided to the overhead condenser by using a waste heat chiller. Runs were made with chilled water at both $50^{\circ} \mathrm{F}$ and $40^{\circ} \mathrm{F}$. The decrease in net energy input required corresponds to a reduction of $\approx 17.5 \%$ in reboiler duty when chilled water is provided at $50^{\circ} \mathrm{F}$. When chilled water is provided at $40^{\circ} \mathrm{F}$, the decrease in reboiler duty is greater - about $25 \%$.

A second brief preliminary study was conducted by using a different analysis to evaluate the merits of using chilled water to reduce the cooling water temperature to the distillation column. In this study, reduced-temperature cooling water was provided to the overhead condenser and for interstage cooling in several pumparound loops on a 100,000-bbl/day atmospheric crude tower. The study determined how much the reboiler or furnace duty could be decreased while keeping the flow rate of each product constant within $0.3 \%$.

To handle the complex calculations involved, a relatively sophisticated computer simulation software - namely, Aspen Plus ${ }^{\circledR}$ - was used. The tower is fed with crude having an API gravity assay of 34 . This complex mixture is modeled by Aspen by using a distribution of 47 components with up to 78 carbon atoms in the one having the highest molecular weight. Aspen models the tower (shown in Figure 2.6) as a fairly typical crude fractionator having two pumparound loops for interstage cooling and three sidestrippers for removal of products named kerosene, diesel, and atmospheric gas oil (AGO). The overhead product is heavy naphtha, while the bottoms product is residual crude (RED-CRD). The crude feed enters the tower on stage 22 of 25 equilibrium stages after being heated in a furnace having a duty of 200 million Btu/h for the base case (this duty is a dependent variable calculated to satisfy the energy requirements of the tower). The three separate sidestrippers are fed with fixed flows of steam at $400^{\circ} \mathrm{F}$ and 60 psia. The pressure at the bottom of the tower is 10 psig, while the top is 6 psig.

For a $5 \%$ increase in the cooling duty ( 2.75 million Btu) on this tower, the furnace duty may be reduced by 12.2 million $\mathrm{Btu} / \mathrm{h}$ without changing the product rates. The reduction in furnace duty is 4.4 times the values of the increases in cooling duty. A rough economic analysis of the chiller system was made on the basis of three assumptions: (1) a COP of an advanced absorption refrigeration unit of $0.8,(2)$ refrigeration unit costs of $\$ 1,500 /$ ton, and (3) energy savings 


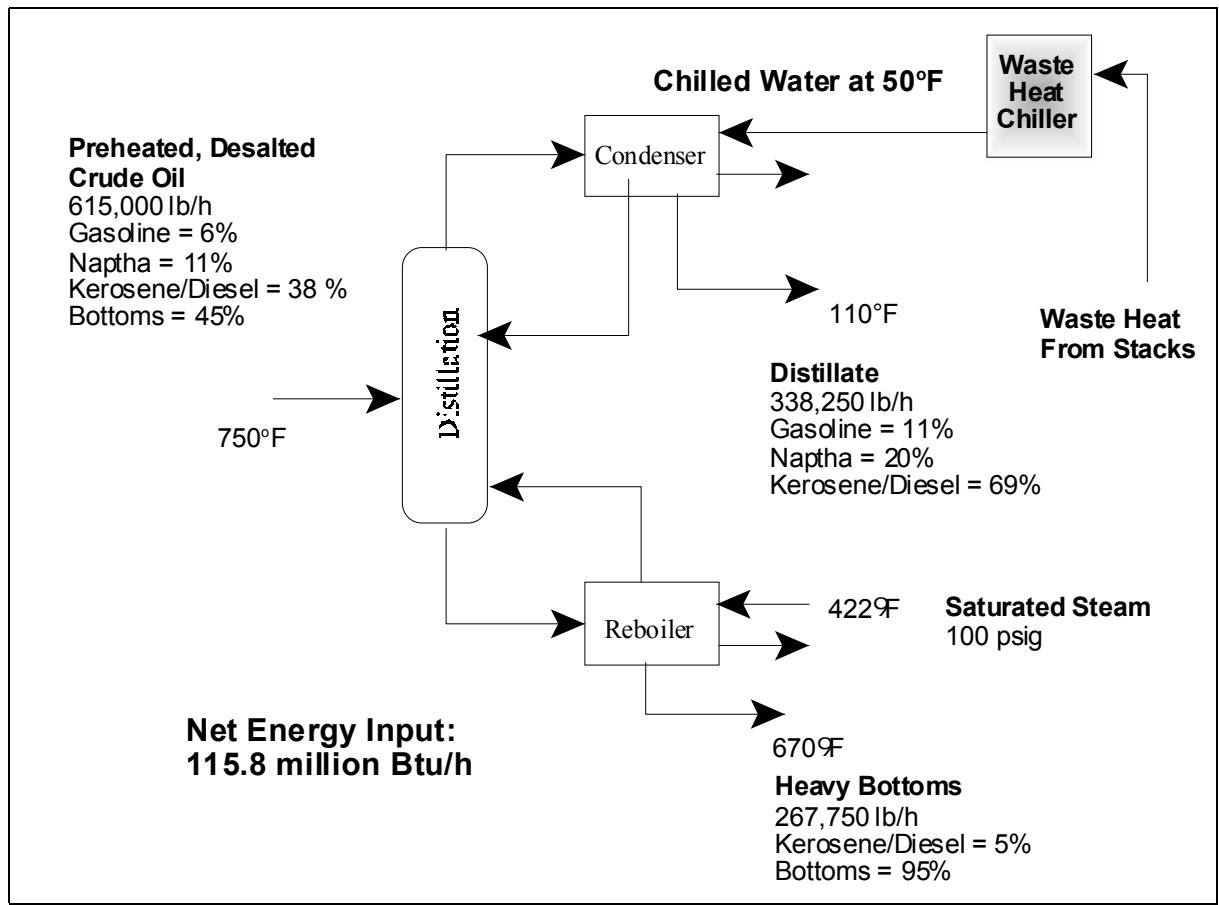

Figure 2.4 Process Diagram for Atmospheric Crude Distillation Using Ambient Condenser Water/CAAPS Simulation

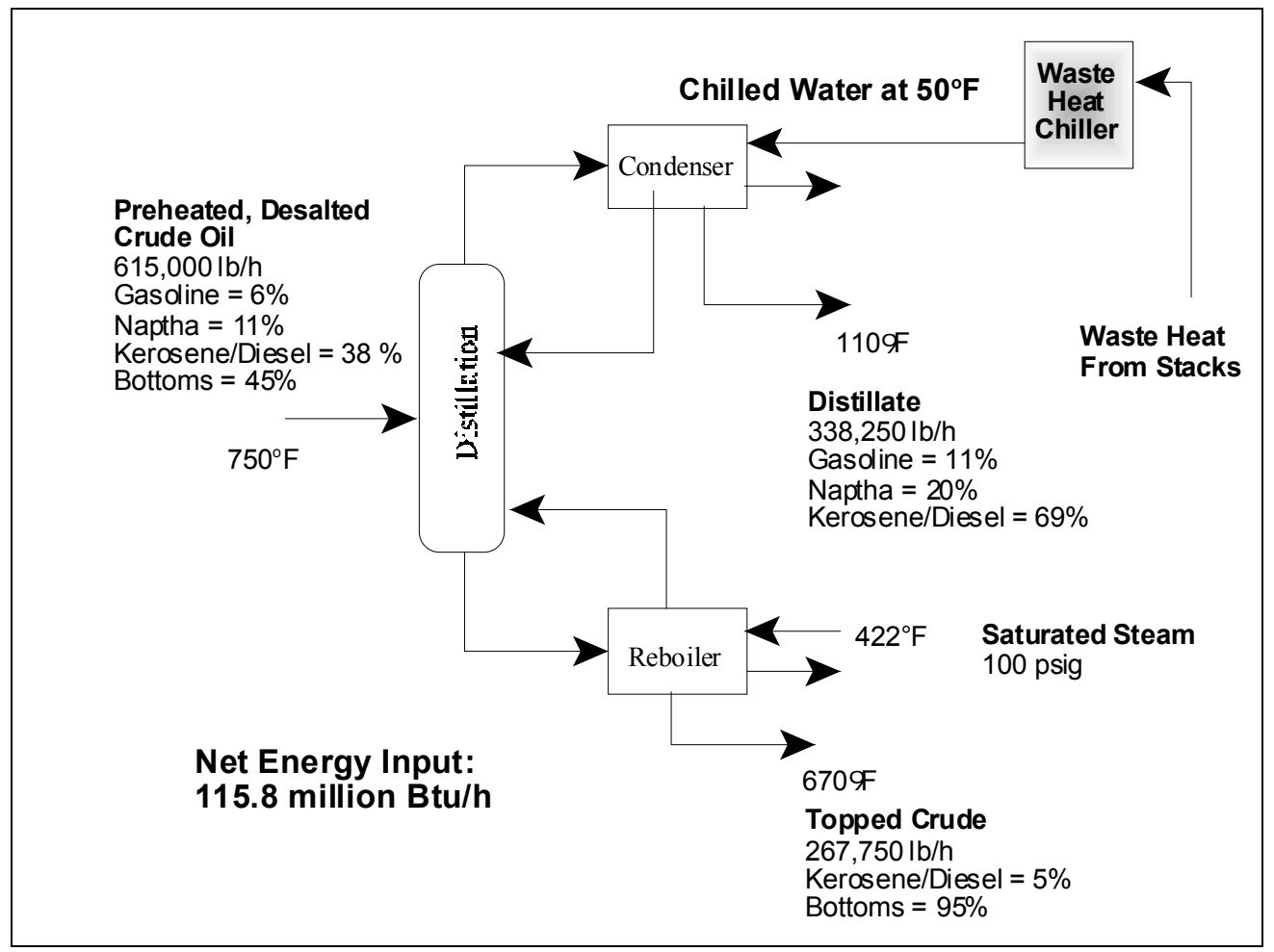

Figure 2.5 Process Diagram for Atmospheric Crude Distillation Using Chilled Condenser Water/CAAPS Simulation 


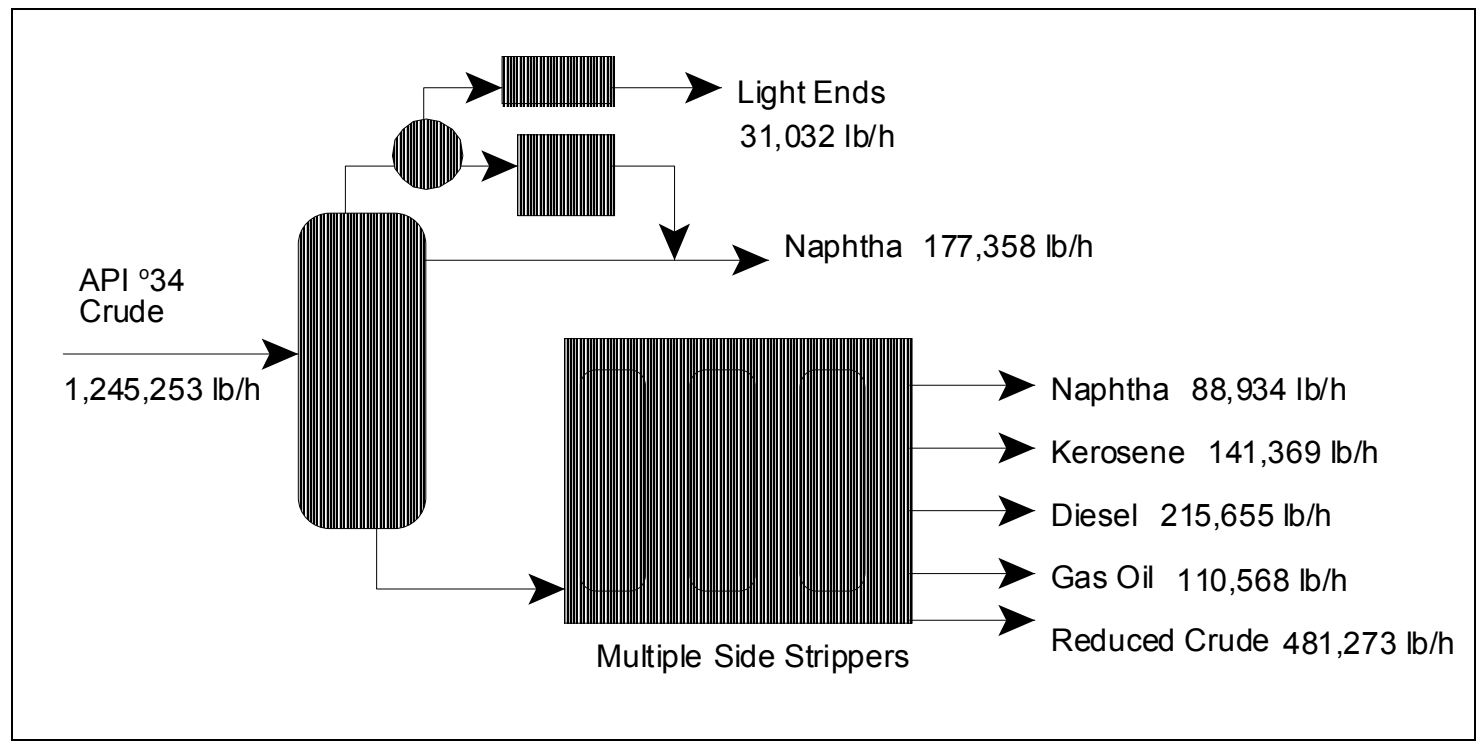

Figure 2.6 Schematic of Crude Distillation Modeled by Aspen®

equivalent to a crude price of $\$ 15 / \mathrm{bbl}$. The analysis indicated a payback period of $1.0-2.0 \mathrm{yr}$, which is consistent with the experience at the Denver refinery. The need to adjust (lower) the pressure of the atmospheric tower by incorporating a lower $\Delta \mathrm{P}$ tray design was, however, not factored into the analysis. More detailed and comprehensive studies of specific towers need to be undertaken to establish the economic viability of utilizing chilled cooling water.

The results from the two studies are relatively consistent. Table 2.2 provides estimates of the potential reductions in energy utilization that could be derived by using waste heat chillers to reduce cooling water temperatures for the atmospheric distillation towers on the basis of these two very preliminary analyses. The table compares the difference in net energy input that results from lowering the temperature of the incoming condenser cooling water by $25^{\circ} \mathrm{F}$ and $35^{\circ} \mathrm{F}$. As is evident, the impacts are substantial for a modest penetration rate of the modification into refineries by 2010 . If similar reductions could be applied to the vacuum distillation tower, significant reductions in energy and carbon emissions are achieved. An estimate of these impacts was made by applying a $17.7 \%$ reduction to about $30 \%$ of the vacuum distillation market in 2010 (see Table 2.3).

There are many other opportunities to apply chilling in the refinery complex to improve yield and reduce energy requirements for distillation (e.g., fluidized catalytic crackers, side strippers, hydrotreating units). The combined impacts from these applications would be substantial. Further, while both analyses used assumed constant product rates, an additional potential benefit would be an increase in overhead product yield (more product for the same feed input) because of the lower reflux ratio. The increase in product rate could provide a considerable reduction in feedstock and process energy; this phenomenon is not addressed here. 
Table 2.2 Estimated Reduction in Energy Requirements and Carbon Emissions from Utilization of Waste Heat Chillers on Atmospheric Distillation

\begin{tabular}{|c|c|c|c|c|}
\hline Condition & $\begin{array}{c}\text { Per Barrel } \\
\text { Reboiler Duty } \\
\text { (Btu/bbl) }\end{array}$ & $\begin{array}{c}\text { Annual } \\
\text { Reboiler Duty } \\
\left(10^{12} \text { Btu/yr) }\right.\end{array}$ & $\begin{array}{c}\text { Annual Energy } \\
\text { Reduction in } 2010^{a} \\
\left(10^{12} \mathrm{Btu} / \mathrm{yr}\right)\end{array}$ & $\begin{array}{l}\text { Reduction in } \\
\text { Carbon Emissions } \\
\text { in } 2010 \text { (MMTCE) }\end{array}$ \\
\hline Ambient Water Conditions & 78,700 & 1.20 & -- & -- \\
\hline Chilled Water $\left(50^{\circ} \mathrm{F}\right)$ & 64,744 & 0.99 & 23.10 & 0.39 \\
\hline Chilled Water $\left(40^{\circ} \mathrm{F}\right)$ & 59,163 & 0.90 & 32.24 & 0.55 \\
\hline
\end{tabular}

a Assumes $30 \%$ penetration of atmospheric distillation units in 2010 .

Table 2.3 Estimated Reduction in Energy Requirements and Carbon Emissions from Utilization of Waste Heat Chillers on Vacuum Distillation Columns

\begin{tabular}{|ccc|}
\hline $\begin{array}{c}\text { Energy Savings/Vacuum } \\
\text { Distillation } \\
\left(\mathbf{1 0}^{3} \text { Btu/bbl) }\right.\end{array}$ & $\begin{array}{c}\text { Total Energy Savings in } \mathbf{2 0 1 0}^{\mathrm{a}} \\
\left.\mathbf{( 1 0}^{\mathbf{1 2}} \mathbf{B t u} / \mathbf{y r}\right)\end{array}$ & $\begin{array}{c}\text { Reduction in Carbon } \\
\text { Emissions in 2010 } \\
\text { (MMTCE) }\end{array}$ \\
\hline 15.6 & 11.62 & 0.22 \\
\hline
\end{tabular}

a Assumes 30\% penetration of vacuum distillation units in 2010 .

\subsubsection{Steam Systems}

Steam is used for a number of purposes throughout the refinery and accounts for $\approx 20 \%$ of energy use. It is used as a stripping agent, in vacuum jets, as a heating medium, and in powering turbines and pumps. A number of opportunities exist to increase steam (energy) utilization efficiency. Letdown valves can be replaced with back-pressure turbines to reduce pressures to the desired intermediate levels and, in so doing, produce electrical power supplanting purchased power. Steam-driven ejector systems and condensing turbines that drive, for example, pumps and blowers can be replaced by the new generation of more-efficient electrical motors, thus generating a net reduction in energy usage. More vigorous maintenance of steam traps, valves, and rapid repair of other steam leaks can also generate significant steam savings. Finally, controlled reduction of stripping steam not only reduces direct energy consumption but also makes fractionation more efficient in the top of the tower and thus reduces the reflux or pumparound requirements to meet separation specifications. Reducing stripping steam, in turn, reduces energy required in the sour water stripper.

The opportunities for reducing steam usage cited can be best accomplished in conjunction with the introduction and integration of a state-of-the-art cogeneration plant into the refinery and optimizing both steam and electricity use, as discussed in Section 3. 


\subsubsection{Fuel-Gas System}

The refinery fuel-gas system supplies about one-half to two-thirds of the energy consumed in the refining process. The fuel gas is derived from the various conversion processes in the refinery. The heat content of the gases' combustion products can, under certain conditions, actually exceed the total energy requirements of the refinery; the refinery then has excess energy. Traditionally, the excess fuel-gas problem has been addressed by tolerating inefficient combustion, generating excess steam, and flaring (burning) the gas into the atmosphere. The excess gas (energy) problem, if it exists in a refinery, is generally exacerbated in the summer when the light-ends separation systems are overtaxed, thus generating additional losses of propane and other higher-heating-value products into the fuel gas system.

A number of opportunities can be pursued to "recover" a greater fraction of the fuel gas (excess energy). Examples of potential solutions include (1) generating additional electrical energy via an on-site cogeneration plant to reduce electrical purchases from utilities; (2) selling the gas to a utility (if one exists near by); (3) isolating and utilizing high hydrogen containing streams as feed to the hydrogen plant, thus supplanting the usual methane (purchased gas) feed; and (4) utilizing waste-heat-driven absorption refrigeration systems to recover the heavier hydrocarbon products from the fuel streams, as described previously. 


\section{Section 3 \\ Mid-Term Opportunities for Improving Refinery Efficiency}

Major opportunities to reduce energy usage in the mid-term are available through modification, retrofitting, and/or replacement of existing equipment nearing the end of its useful life and during major refinery revamps that are periodically undertaken to meet market/environmental dictates. Examples of such opportunities are discussed in the following sections.

\subsection{Combustion Efficiency Improvements in Fired (Process) Heaters/Boilers}

As indicated previously, over $60 \%$ of the energy used in refineries is obtained from burning gaseous fuels in refinery heaters/furnaces. Therefore, improving the overall combustion efficiency of the heaters and boilers is a major target of opportunity. The problem of improving the efficiency of combustion systems is complicated by the fact that they need to be fuel-flexible and must meet increasingly stringent environmental emission regulations. Various approaches have been suggested and considered that seek to alter furnace designs and control to improve efficiency. They range from plausible to proven (with varying degrees of economic viability). The following examples of opportunity are cited primarily to illustrate this broad range of possibilities.

To maximize energy-use efficiency, the quantities of fuel used must be minimized and the heat recovery maximized to reduce the amount discharged to the environment. One approach to reduce fuel consumption is to improve the heat-release profile in the heater/boiler to improve overall heat-transfer characteristics. Heat-release profiling seeks to match heat release with load and the flame shape with process tube configuration. As an example, such profiling can be achieved with radiant burners, which can be designed to conform to the shape of the load and thus can concentrate heat where it is needed. (Radiant burners are generally more expensive than conventional burners, however.) Another approach is to improve heat-transfer characteristics through enhancing flame luminosity. A variety of luminosity-enhancing techniques have been tried with varying degrees of success. The use of oscillating (pulsed) combustion, in which the fuel flow is oscillated while the airflow remains constant, has been studied; this technique potentially can realize efficiency gains of $5-10 \%$ in process heater applications. The use of recouperators to recover energy (e.g., air preheat) is possible, especially for higher temperature processes; however, cost and an increase in $\mathrm{NO}_{\mathrm{x}}$ emissions constrain the use of this approach. A promising route for improving boiler/furnace efficiency is through incorporation of improved sensors and controls. For example, balancing the burners in a multiburner unit and reducing excess air can cut fuel use significantly. In single-burner boilers, excess air control can also produce similar improvement. The technology to automate excess air firing is available.

Economics, unavoidable heat losses, and dewpoint considerations restrict maximum furnace thermal efficiency to $\approx 92 \%$. Since the thermal efficiency of most furnaces in the industry is 
between 75 and $90 \%$, the maximum achievable improvement appears to be $\approx 10 \%$. The potential energy savings and reductions in $\mathrm{CO}_{2}$ emissions from improving heater/furnace/boiler efficiencies by only $5 \%$ is very large, as shown in Table 3.1 .

Table 3.1 Potential Carbon Emission Reductions from Improved Combustion Efficiency

\begin{tabular}{|c|c|c|}
\hline $\begin{array}{l}\text { Projected Energy Use in } \\
2010 \text { for Heat and Power } \\
\text { (1012 Btu) }\end{array}$ & $\begin{array}{c}\text { Potential Energy Savings } \\
\text { (5\% Improvement) } \\
\text { (1012 Btu) }\end{array}$ & $\begin{array}{l}\text { Potential Carbon } \\
\text { Reduction in } 2010 \\
\text { (MMTCE) }\end{array}$ \\
\hline $4,598.1$ & 229.9 & 4.3 \\
\hline
\end{tabular}

Note: Energy use was projected on the basis of a $0.9 \%$ annual increase (Annual Energy Outlook 1997, Energy Information Administration).

\subsection{Fluidized Catalytic Cracking}

Substantive reductions in total industry energy usage can be achieved through modification of key processes to increase efficiency and/or increase product yields per barrel processed to meet market demand. Increasing product yields not only reduces energy usage and emissions but also improves competitiveness.

Catalytic cracking is used to upgrade heavy gas oils to high-octane gasoline, light oils, and light gases (e.g., olefins). The catalytic cracker is often central to the operation of the refinery because of its adaptability to changing feedstocks and product demands and because of the high margins between feedstock and products. FCC currently produces approximately $40 \%$ of the country's gasoline pool. FCC thus represents an especially attractive target of opportunity because it is now, and is likely to continue to be, the key process for meeting demand for "white products."

The product slate yields from FCC can be adjusted by modifying operating parameters in the riser reactor (e.g., residence time, such equipment as feed nozzles, and injection locations) and by utilizing improved catalysts. However, the flow environment in the FCC unit is highly complex (e.g., reacting, multi-phase flows), and optimized operation is difficult to attain. Advanced analytical design and operational tools are under development [16-18] that can be used to define and evaluate optimized FCC operating conditions and hardware improvements to enhance yields of desirable products. The tool essentially consists of a three-dimensional integrated hydrodynamic-kinetic model for predicting the interaction between FCC chemistry and fluid dynamics. Studies have shown that optimization of the FCC unit with appropriate modifications of equipment and operating conditions can increase the yield of FCC high-octane gasoline and alkylate from $3 \%$ to $7 \%$ per barrel of crude $[17,19]$.

An analysis of the impact of increasing the desired product yield of FCC by $7 \%$ indicates that if this could be implemented across the refining industry, energy savings could reach 36 trillion Btu/yr [20]. The analysis assumes that $100 \%$ of operating units are revamped by 2010 . The estimated reduction in energy use and carbon emissions resulting from optimizing FCC 
operation are shown in Table 3.2. The expected shift to lower quality (lower API gravity and higher sulfur) crudes expected in the future will likely impact achievable savings because of their impact on the performance of the fluidized catalytic cracker. From an energy-recovery viewpoint, however, the expected increases in coke (carbon) laydown on the fluidized catalytic cracking catalyst will increase opportunities for heat generation from fluidized catalytic cracking and, thus, turn it into an even greater exporter of energy. Additional heat-recovery equipment would have to be installed, such as catalyst coolers and $\mathrm{CO}$ boilers that can be used for the generation of, for example, additional steam air preheat or for the production of electric power. Judicious integration of the excess heat into the refinery utility system would thus reduce the consumption of other fuels (such as gas and electricity) purchased from utilities.

Table 3.2 Reduction in Energy Use and Carbon Emissions Resulting from Increased Yields from Optimized FCC

\begin{tabular}{|cccc|}
\hline Year & $\begin{array}{c}\text { Energy Reduction } \\
\left(\mathbf{1 0}^{\mathbf{1 2}} \mathbf{B t u}\right)\end{array}$ & $\begin{array}{c}\text { Reduction in Carbon } \\
\text { Emissions (MMT CO })\end{array}$ & $\begin{array}{c}\text { Reduction in Carbon } \\
\text { Emissions (MMTCE) }\end{array}$ \\
\hline 2010 & 36.0 & 2.44 & 0.67 \\
\hline
\end{tabular}

\subsection{Distillation}

Approximately one-fourth of the energy used in refining is in the crude distillation process [21]; it can be as high as $40-70 \%$ for the whole refinery. Accordingly, a number of studies have been undertaken to identify opportunities to reduce energy usage in distillation. One example, reducing condenser temperature, has already been discussed. Other substantive opportunities to reduce energy usage undoubtedly exist and can be identified through detailed energy analyses. As an example, an energy analysis was conducted to identify where, within a distillation installation, the highest potential exists to reduce energy consumption [22]. Not surprisingly, the equipment/subsystems with the greatest potential for improvement identified were the fired heater, condensate reflux system, the crude preheating train, and the effluent cooling train.

The opportunities identified underscore the importance of enhancing combustion efficiency and improving waste heat recovery. The results from the energy analysis are consistent with the most frequently recommended modifications to the distillation processes, which are summarized in $[23,24]$, namely (1) improving fired heater combustion efficiency through modification of the burners, applying advanced control technology, and using a recuperative air preheater (these modifications were discussed previously); (2) incorporating staged crude preheat; and (3) replacing stream ejector vacuum pumps with efficient, electrically driven mechanical vacuum pumps. Other recommended actions to improve distillation energy efficiency include

(1) selectively introducing vapor recompression into the overhead reflux condenser subsystem (e.g., in the depropanizer column) [25], (2) improving heat recovery and integration between the crude and vacuum distillation units (estimates of reduction of distillation energy usage in refineries where the two units are not integrated range from 10 to 20\%) [23], and (3) substituting reboilers heated by the main column bottom for the stripping steam in the stripping columns [22]. 
More limited opportunities are available to improve the efficiency of the distillation tower (process) itself; for example, optimizing the number of trays or using more efficient packings. The greatest potential for improving distillation efficiency would require major revamps of towers to essentially alter the distillation process by increasing the number of heat-integrated (internal) condensing steps, thus reducing the loads on the fired heater and main condenser. Opportunities to improve distillation efficiency through such steps are limited. Nevertheless, there are significant opportunities (and the motivation) to reduce energy consumption in the refinery distillation processes; a 10\% reduction in energy use would reduce overall refinery energy consumption by about $4-7 \%$.

\subsection{Heat Integration and Fouling Mitigation}

Process heat recovery and integration is one of the most effective means for reducing energy usage in the refinery. The objective is to identify, capture, and utilize the waste heat that is generated when process streams are cooled and/or that result from the combustion of the variety of fuels used in the refinery (e.g., from fired heaters). At times, the industry has, in fact, pursued process heat recovery and integration vigorously when economically justified (e.g., under highcost energy conditions, such as those during the 1970s). An example of such a success is given in [26], wherein a major refiner reported that its refinery energy efficiency was improved by about 25\% between 1969 and 1981; a significant fraction of the improvement was due to enhanced heat integration. Opportunities for heat integration are readily identified through the application of pinch technology analysis.

Pinch technology analysis develops a composite heat availability/recovery balance sheet that can be used to identify which equipment can be most advantageously modified, added, or relocated to debottleneck the heat recovery system and thus to achieve the highest energy recovery most cost-effectively $[5,12]$. Thus, the application of pinch technology in the refinery allows engineers to track the heat flow from all process streams within a plant, thereby facilitating identification of heat integration opportunities between major plant equipment and subsystems to achieve optimum energy efficiency. Pinch technology often identifies where heat-exchange systems are placed improperly and operating inefficiently.

The benefits of heat integration derived from pinch analysis are many and well documented. Refineries implementing these projects have reported major fuel energy savings along with substantial reductions in pollutant emissions and other waste products (e.g., desalter brine, wastewater). Overall, reductions in energy consumption of from 20 to $40 \%$ have been reported from a number of sources [27-31].

Undoubtedly, there are substantial additional opportunities to achieve enhanced integration, assuming that a lower ROI can be justified and the issue of capital availability can be resolved. Separation systems (e.g., distillation towers) represent primary opportunities for heat integration in the refinery through pinch technology. One of the most promising opportunities in which heat integration can substantially reduce energy use is between the crude and vacuum distillation towers. Two studies $[32,33]$ have indicated potential energy saving in excess of $10 \%$, with payback in less than 2 years. A challenging opportunity is the recovery of heat from the overhead 
atmospheric condenser; this represents a large quantity of low-grade heat. While some refineries recover heat from this stream to preheat crude and border feed water, it is usually not recovered. The judicious application of enhanced cooling to distillation towers yields further substantive opportunities to improve heat integration across the refinery complex by lowering tower bottom temperatures and opening up the temperature differences between the reboiled fluid and the energy source.

Gains in energy utilization efficiency achieved through heat integration can be readily lost unless aggressive programs are implemented to minimize and control heat exchanger fouling. Heat exchangers, including furnaces, are the workhorses in refineries. A typical modern refinery is equipped with hundreds of heat exchangers of various sizes. The overall energy efficiency of refineries depends heavily on heat integration achieved in feed/effluent heat exchangers that recover thermal energy from high-temperature processes. Foulant buildup impedes heat transfer and, thus, reduces heat flow; also, in fired heaters, the lost energy must be compensated by burning additional gas or liquid fuels in furnaces. Thus, fouling of equipment significantly reduces the energy-use efficiency of process operations and increases capital and operating costs. The resulting economic and energy costs for U.S. refineries are well known: 0.2 Quads of energy (about $6.5 \%$ of the total energy consumed in refining) and more than $\$ 2$ billion are lost each year because of fouling [34]. The total worldwide energy and cost penalties range from 8 to 10 times that of U.S. refineries. The fouling problem (energy inefficiency) will become more critical as more heavy oil and residuum is processed in the future.

Fouling in heat-exchange equipment in refineries can be better controlled if threshold fouling is identified and circumvented. The development of an analytical methodology for predicting threshold fouling conditions is under way and is expected to be available commercially after 2000 [35]. This analytical tool consists of a knowledge-based model that examines the interactive effects of fluid dynamics, heat/mass transfer, and chemical reactions associated with fouling precursors, followed by deposition of the foulant on the heat-exchange surface. The model uses fouling data obtained in the laboratory with a closed-flow loop apparatus, along with data obtained in the field at operating refineries, to model industrial applications of once-through flow systems. The initial emphasis is on fouling mitigation of preheat-train exchangers for crude distillation units and other heat exchangers used in the production of fuel products (e.g., gas oil, middle distillates, naphtha). In addition to predicting threshold conditions for fouling, the model also permits evaluation of potential changes in fouling characteristics that arise from changes in operating conditions and feedstock quality.

An analysis of the energy impacts of fouling mitigation strategies performed by the developers of this technology suggests that it may be possible to achieve a $30 \%$ reduction in process-heater load from controlling fouling in this preheat train and furnace [36]. This improvement results not only from a reduced heat load, but also from a reduction in the number of incidents of tube failures. The reduction in carbon emissions associated with such an improvement has been estimated and is shown in Table 3.3. 
Table 3.3 Potential Carbon Emission Reductions from Improved Distillation Processes

\begin{tabular}{|c|c|c|}
\hline $\begin{array}{l}\text { Projected Energy Use in } \\
2010 \text { for Heat and Power }\end{array}$ & $\begin{array}{l}\text { Potential Energy Savings } \\
\text { ( } 2 \% \text { improvement in overall } \\
\text { refinery use) }\left(10^{12} \mathrm{Btu}\right)\end{array}$ & $\begin{array}{l}\text { Potential Carbon } \\
\text { Reduction in } \\
2010 \text { (MMTCE) }\end{array}$ \\
\hline $4,598.1$ & 92.2 & 1.7 \\
\hline
\end{tabular}

Note: Energy use was projected based on a $0.9 \%$ annual increase (Annual Energy Outlook 1997, Energy Information Administration, Washington, D.C.).

\subsection{Coke/Residue Gasification for Co- and Trigeneration/ $\mathrm{H}_{2}$ Production}

The gasification technology that exists today provides refiners with a unique opportunity, albeit a costly one, to simultaneously improve energy utilization, reduce emissions, and add value to the bottom of the barrel by converting the coke and waste residues to a synthesis gas that can be used for producing electricity, process steam, and $\mathrm{H}_{2}$. The integration of a coke/residue gasifier with a cogeneration plant and $\mathrm{H}_{2}$ production system would provide refiners with an enhanced capability to process the lower quality petroleum feeds (expected in the future) to meet changing market product demand and environmentally mandated specifications. The technology would also allow the refiner to become an exporter of energy and provide an inherent capability to dispose of various problem liquid/solid carbonaceous residues.

The gasifier converts the various residues into a clean syngas (composed of $\mathrm{H}_{2}$ and $\mathrm{CO}$ ), which can then be split into several streams that can be fed into a cogeneration plant to produce electricity and steam at desired pressure levels and to a $\mathrm{H}_{2}$ plant. If desired, the syngas can also be fed into the fuel gas system and used as the fuel for fired heaters. The conventional cleanup process used in the gasification system recovers the sulfur from the fuel gas in the elemental state and thus reduces $\mathrm{SO}_{2}$ emissions dramatically. The cleanup system can also be sized to clean up segments of the primary fuel gas stream. Any excess electrical power generated in the cogeneration plant can be fed into a utility grid stream. Incorporation of a cogeneration plant also provides the capability to optimize the steam utility system. The syngas generated from the lowvalue residual waste thus supplants natural gas normally needed to augment the refinery's fuel gas supply and that used for the production of $\mathrm{H}_{2}$. The technology is already being introduced into various refineries $[10,37]$.

\subsubsection{Trigeneration}

Cogeneration systems can readily be adapted to produce refrigeration cooling capacity as well and essentially function as a trigeneration plant. As indicated previously, the judicious application of enhanced cooling to various process streams can have major impacts on and/or open up opportunities for reducing energy use in a refinery. Major increases in the demand for refrigeration cooling capacity could most readily be met by a trigeneration plant. A trigeneration plant would also provide a greater flexibility in meeting seasonable fluctuations in peak demand for electricity, steam, and refrigeration capacity. A review of the characteristics and features of trigeneration plants is given in [38]. 


\subsubsection{Impact on Energy-Use Efficiency}

The specific gains that can be achieved in energy-use efficiency $\left(\mathrm{CO}_{2}\right.$ reduction) from the introduction and integration of a gasification $-\mathrm{H}_{2}$, co-/trigeneration plant into a refinery is site-specific and thus cannot be generalized for the industry. In-depth studies would be required for each site. It should be noted, however, that industries that make significant use of both power and process heat (e.g., chemicals, petroleum refining, pulp and paper making, food processing) are increasingly looking to cogeneration to provide a share of their energy needs. Cogeneration capacity in petroleum refineries in 1994 was estimated to be about 2,260 $\mathrm{MWe}$ [39] and is steadily increasing.

Cogeneration systems in refineries comprise a variety of configurations using a range of fuels. They can include both topping and bottoming cycles (combined cycles) or single-turbine systems. Natural-gas-fired turbines, expansion turbines, coke-fired fluidized-bed steam generators, and gas-fired boilers have all been used in refineries to provide power and process heat. A recent major refinery modification planned [37] or under way [10] that incorporates such plants suggests that the benefits are significant and the incorporation of such plants is economically viable.

The development of advanced cogeneration technologies now under way, such as advanced turbine systems and fuel cells, will undoubtedly increase the motivation to incorporate such plants in refineries. Developments to-date indicate that the advanced turbines have the potential to increase overall efficiency in stand-alone simple cogeneration plants by as much as 13 percentage points and the fuel cells by 24 percentage points. Market penetration studies [18] of the two technologies indicate the incorporation of the advanced technologies into the existing and projected cogeneration capacity in the industry would generate carbon reductions of 0.56 MMTCE by 2010 and 1.0 MMTCE by 2020 (see Table 3.4). According to recent studies, there is an estimated $10,000 \mathrm{MW}$ of cogeneration potential in the petroleum refining industry [40-42], with about $50 \%$ of that achievable by 2010 . If this potential were achieved, substantial reductions in energy consumption and associated carbon emissions would be possible.

Table 3.5 provides projections of the potential reductions based on replacing average utility heat rates (roughly 33\% efficiency) with cogeneration units that are much more efficient (43\% efficiency). This estimate is considered very conservative, as efficiencies of up to $53 \%$ have been reported for cogeneration systems. Furthermore, even higher overall thermal efficiencies $(\approx 70 \%)$ can be expected from highly integrated co- and trigeneration systems. 
Table 3.4 Reduction of Energy Requirements and Carbon Emissions and Reduction in Fouling in Crude Preheat Train

\begin{tabular}{|ccccc|}
\hline $\begin{array}{c}\text { Traditional Fouling } \\
\text { Environment } \\
\left(\mathbf{1 0}^{3} \text { Btu/bbl) }\right.\end{array}$ & $\begin{array}{c}\text { With Reduction } \\
\text { in Fouling } \\
\left(\mathbf{1 0}^{3} \mathbf{B t u} / \mathbf{b b l}\right)\end{array}$ & $\begin{array}{c}\text { Reduction in } \\
\text { Consumption } \\
\left(\mathbf{1 0}^{3} \mathbf{B t u} / \mathbf{b b l}\right)\end{array}$ & $\begin{array}{c}\text { Annual Energy } \\
\text { Reduction in 2010 } \\
\left(\mathbf{1 0}^{\mathbf{1 2}} \mathrm{Btu}\right)\end{array}$ & $\begin{array}{c}\text { Reduction in Carbon } \\
\text { Emissions in 2010 } \\
\text { (MMTCE) }\end{array}$ \\
\hline 632.9 & 599.5 & 33.4 & 55.12 & 1.03 \\
\hline
\end{tabular}

Note: Assumes $60 \%$ of process heaters/furnace units used for crude distillation preheat will use the fouling mitigation tool to improve energy efficiency and reduce downtime.

\subsection{Solid Catalyst Alkylation Technology}

Alkylation is used in petroleum refineries to upgrade light gases to clean, high-octane gasoline blending stock that is particularly suitable for reformulated gasoline production. The feedstocks for alkylation typically include a mixture of light olefins (propylene, butylene, amylene, pentylene, pentenes) combined with isobutane. Alkylation processes currently use either a sulfuric acid $\left(\mathrm{H}_{2} \mathrm{SO}_{4}\right)$ or hydrofluoric acid (HF) catalyst, with somewhat different process configurations. HF processes require less acid catalyst per barrel of alkylate than sulfuric acid processes, operate at about $38^{\circ} \mathrm{C}$, and use cooling water for temperature control. HF processes can, however, release toxic vapors and injure the surrounding community and must be equipped with costly containment and monitoring systems to prevent emissions. Legislation has already been proposed in California to ban the large-scale storage of HF, which, if passed, would force users of HF alkylation systems to switch to a less-hazardous process. Sulfuric acid processes use more acid per barrel of alkylate and require refrigeration or cooling to subambient temperatures, but they are less hazardous to operate.

Solid acid alkylation catalysts have been under development for a number of years as an alternative to liquid acid catalysts. Using a solid acid catalyst for alkylation would be more environmentally sound than using current liquid acid processes and would require considerably less energy, particularly if operated at ambient temperatures. Several solid acid catalysts are currently in pilot-stage development and have been designed for use in fixed-bed, fluidized-bed, or slurry reactors [43]. A reactor system similar to that used for FCC was recently patented and includes a catalyst regenerator with continuous operation [44].

To evaluate the potential impact on carbon emissions possible through the replacement of liquid acid catalysts, a possible solid acid catalyst process was devised on the basis of currently available data. It is illustrated in Figure 3.1. The process assumes that a fluidized-bed reactor is used that has energy requirements similar to those of a fluidized catalytic cracker. The process also assumes that an ex-situ catalyst regenerator is used, which generates enough energy to provide cooling for removal of heat from the reaction, which allows the reaction to proceed at or above ambient temperatures. A further assumption is that no net export of energy is available. In actual practice, it appears that there could be significant net steam export. Additional data and more detailed analysis would be needed to determine if, in fact, there would be an energy credit. 
A comparison was made between the current liquid acid alkylation systems and the possible solid acid catalyst on the basis of current average energy requirements for these systems [45]. The comparison assumes that $60 \%$ of alkylate (about 1.1 million barrels per calendar day) is produced by using HF processes. Since growth in alkylates should be greatest in the next 3-5 yr, an annual growth rate of 5\% was applied to current production through 2000 . After 2000, a more conservative growth rate of $1 \%$ percent was assigned through 2020. Replacement of current liquid acid systems was assumed to be about $40 \%$ through 2020 . As shown in Table 3.6, the energy savings and associated reduction in carbon emissions in 2010 could be significant (nearly 40 trillion Btu in 2010).

Table 3.5 Energy Savings and Carbon Reductions from Adoption of Cogeneration in Refineries

\begin{tabular}{|ccccc|}
\hline $\begin{array}{c}\text { Technical Potential } \\
\text { Cogeneration Capacity } \\
\text { by 2010 (MW) }\end{array}$ & $\begin{array}{c}\text { Average Utility } \\
\text { Heat Rate } \\
\text { (Btu/kWh) }\end{array}$ & $\begin{array}{c}\text { Cogeneration } \\
\text { Heat Rate } \\
\text { (Btu/kWh) }\end{array}$ & $\begin{array}{c}\text { Annual Energy } \\
\text { Reduction in 2010 } \\
\text { (1012 Btu) }\end{array}$ & $\begin{array}{c}\text { Reduction in Carbon } \\
\text { Emissions in 2020 } \\
\text { (MMTCE) }\end{array}$ \\
\hline 5,000 & 10,500 & 8,000 & 76.7 & 1.42 \\
\hline
\end{tabular}

Table 3.6 Potential Energy and Carbon Emission Reductions from Replacement of Sulfuric Acid with Solid Acid Alkylation

\begin{tabular}{|ccc|}
$\begin{array}{c}\text { Refrigeration Energy } \\
\text { Consumption for } \mathrm{H}_{\mathbf{2}} \mathbf{S O}_{\mathbf{4}} \\
\text { Alkylation (Btu/bbl alkylate) }\end{array}$ & $\begin{array}{c}\text { Potential Energy } \\
\text { Annual Savings } \\
\left(\mathbf{1 0}^{\mathbf{1 2}} \mathbf{B t u}\right)\end{array}$ & $\begin{array}{c}\text { Potential Carbon } \\
\text { Reduction in } \\
\mathbf{2 0 1 0}\end{array}$ \\
\hline 36,000 & 2.6 & 0.04 \\
\hline
\end{tabular}

Note: Assumes growth in alkylates of $0.9 \%$ annually and penetration of $40 \%$ of sulfuric acid alkylation units by 2010 . 


\section{Section 4 \\ Long-Term Opportunities Requiring Further R\&D}

For the longer term, a number of research directions can be pursued with respect to novel refinery process development or improvements that have the potential to produce breakthroughs in the use of refinery energy and reductions of emissions. New approaches to refining will need to be developed to counteract the pressure of increasing refinery complexity and energy utilization to process lower-quality crudes. Major incentives exist to eliminate or reduce the levels of metals, sulfur, and nitrogen as early as possible in the refining process because of their adverse effect on catalyst performance (i.e., product yields and energy utilization) in such key processes as fluid catalytic cracking, hydrocracking, and hydrotreating. As discussed previously, there is an incentive to reduce energy usage in the crude and vacuum towers, the major consumers of energy in the refining process. Examples of several promising directions that could have major impacts on enhancing refining efficiency are briefly discussed.

\subsection{Refining Process Modifications}

Distillation is used to separate crude oil into its various fractions on the basis of differences in boiling points. The final products from the crude and vacuum distillation units include straight-run gasoline, naphtha/kerosene, heavy and light gas oils, and vacuum residua. Nearly all must be subjected to some form of hydrotreatment to reduce sulfur, carbon, and/or metal content prior to entering downstream processing units (e.g., catalytic crackers or hydrocrackers; alkylation).

An alternative to the use of distillation to effect primary separation is the use of controlled thermal cracking. Thermal cracking can separate crude oil into fractions by "cracking" large hydrocarbon molecules into smaller ones. Ideally, the larger asphaltene-type molecules in the $1,000^{\circ} \mathrm{F}$ fraction could be cracked into lower-boiling-point reactions while the molecular structure of the fractions boiling below $1,000^{\circ} \mathrm{F}$ would not be altered substantially. Available data $[19,46]$ indicate that the large molecules do crack more readily and thus support the concept of using thermal cracking to effect an initial separation.

A potentially attractive refining process modification is to input the crude directly into a "controlled, low-residence-time thermal cracking unit," thereby bypassing the atmospheric and vacuum towers. In addition to achieving initial primary separation, other major improvements in the overall refining process would be expected to evolve. Major fractions of the sulfur, nitrogen, and metals would be removed in the thermal cracking unit, thus reducing operating severity and hydrogen requirements in subsequent hydroprocessing steps. These improvements, in turn, can be expected to generate sizable reductions in energy use. Also, a refinery based on this approach should provide additional flexibility in adjusting product yields. The feasibility of this approach has been addressed in a number of publications [46-50]. 
Perhaps the most noteworthy of the studies is the one reported in [47] that provides a detailed evaluation of the use of the asphalt rendered treating (ART) process in various refinery configurations. The ART process (originally developed by M.W. Kellogg and further developed by Engelhard Corporation) uses noncatalytic, fluidized-solid-bed thermal-cracking units. The study indicated that for a refinery configured to have the crude flow directly into the ART unit, the downstream units would see 30-50\% less sulfur, 50-80\% less nitrogen, and $>95 \%$ fewer asphaltenes and metals. As a result, catalyst volumes and hydrogen requirements would be reduced to achieve the desired product slates. The reduced hydrogen requirements were defined in an experimental study on hydrotreating requirements for the products that are produced from processing a whole Maya crude through an ART unit [48]. This study showed that conventional HGO treating conditions could handle the ART HGO stream. Also, the major fraction of the energy released in the regenerator (up to $80 \%$ ) can be recovered as usable energy.

In a similar study [49], ANL collaborated with California Synfuels to investigate field upgrading of Midway Sunset crude oil. The upgrading was based upon a process wherein the crude was introduced into a fluidized thermal cracking unit followed by hydrogenation of the lighter distillates and mild hydrocracking of the heavy cracked distillates. The results obtained were similar to those as described in the above study [48]. Major reductions in S, N, and metals in the product streams were obtained as cited earlier. The quality of the heavy distillate fractions was better than an atmosphere resid desulfurization product as a fluidized-catalytic-cracker feedstock. As expected, the quality of this heavy cracked distillate (the feedstock to the hydrotreater) can be adjusted by manipulating the coke yields. The coke formed on the noncatalytic solid is converted directly to heat energy, which is sufficient to supply the energy needs of the cracker and generate significant export levels of steam or process energy. The process has an inherent exceptional flexibility for adjusting product yields and energy output. The results of the study indicate that major benefits would occur from incorporating the basic process into a refinery; for example, the large heaters required for distillation coking and for ARDS would be eliminated since the heat from the fluidized-bed cracker can be used to drive the system.

Although the above-cited studies suggest major improvements in energy-use efficiency can be expected from the modification of the refinery process in this manner, no definitive energy savings were cited or apparently developed. To gain perspective, a rough estimate was made of the specific energy and carbon impacts by comparing a refinery using atmospheric and vacuum distillation and delayed coking with a refinery using thermal cracking in combination with mild hydrocracking of heavy distillates and hydrotreating of light distillates. Analyses of both scenarios (see Figures 4.1 and 4.2) are based on data derived from case studies [51] and test data given in [47] and [49]. Each refinery processed Arabian crude (API 28) containing relatively high sulfur and nitrogen; both produce the same amount of coke (12 wt.\% of crude) and use it to generate steam.

The process diagram, yields, and energy requirements for the front end of conventional crude-distillation/delayed-coking refiner configurations shown in Figure 4.1 are based on a detailed case study of processing a heavy crude (API 28; sulfur, 4\%) reported in [51]. The fluidized-bed thermal-cracker/mild-hydrocracker configuration depicted in Figure 4.2 (as well as the energy requirements and the product yields) was derived from the data/information provided 


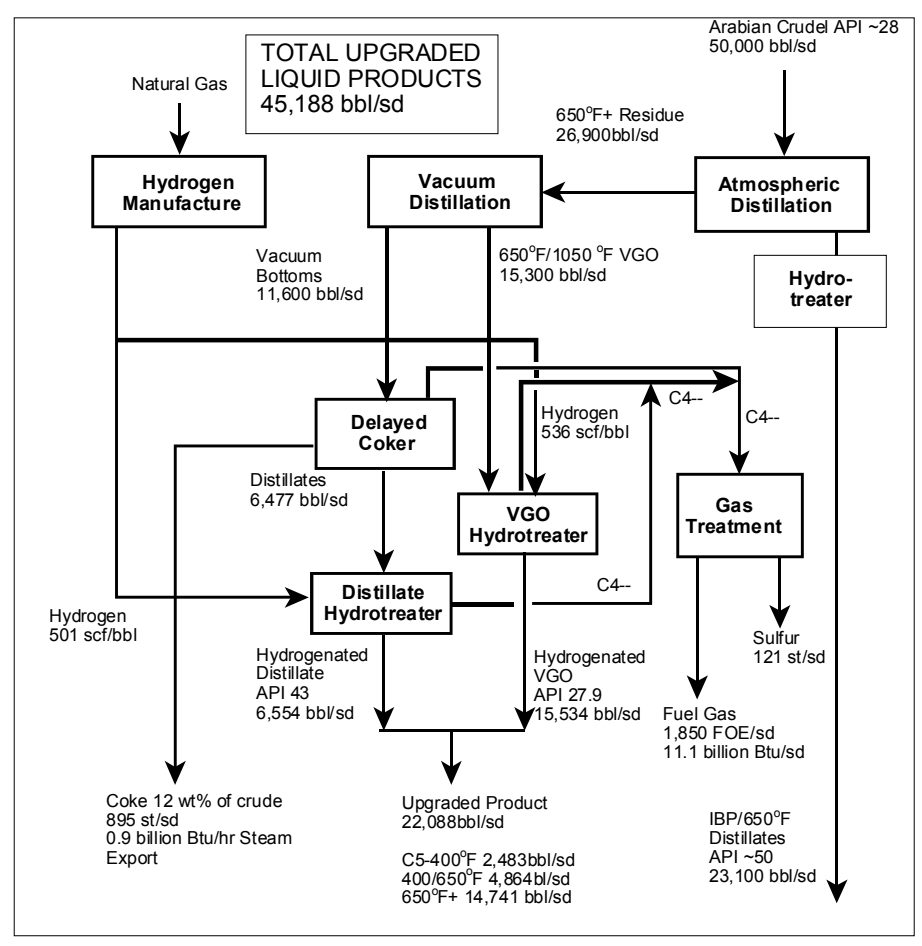

Figure 4.1 Refinery Using Atmospheric/Vacuum Distillation and Delayed Coking to Upgrade Crude

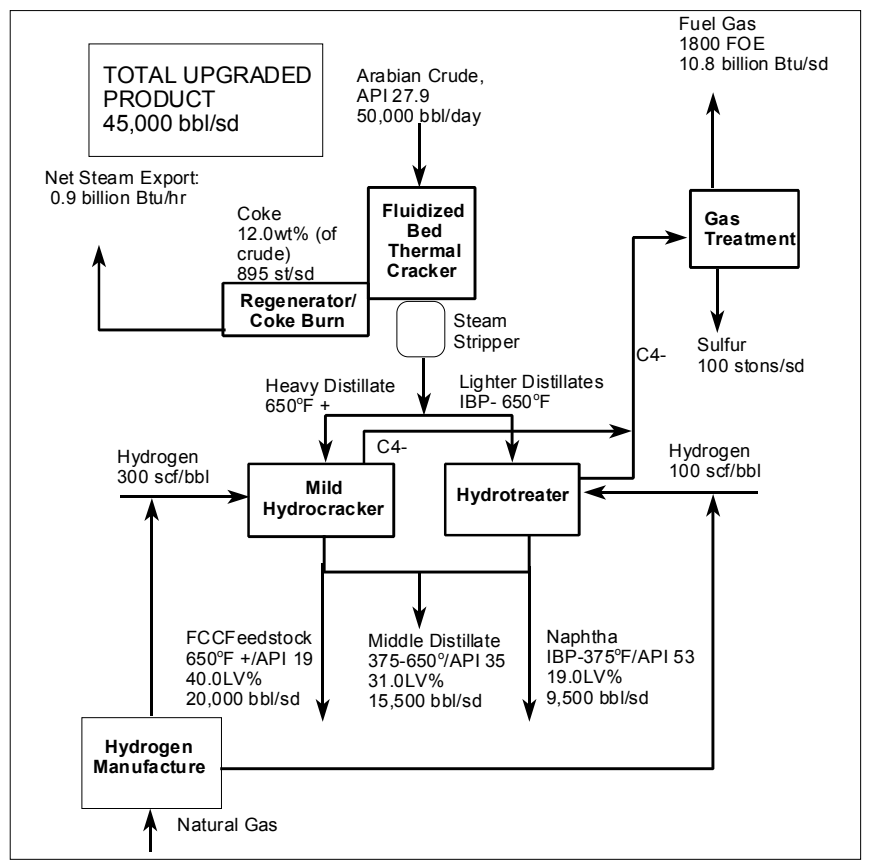

Figure 4.2 Refinery Using Fluidized-Bed Cracking to Upgrade Heavy Crude 
in [47] and [49]. A comparison of energy requirements for the two scenarios is shown in Table 4.1. Projected energy savings and reduction in carbon emissions are shown in Table 4.2. The replacement of the crude distillation scheme with a thermal cracking process results in a net energy savings of about 63,266 Btu per barrel of oil processed. As indicated in Table 4.2, total energy savings in 2010 from the adoption of such an approach could be significant; on the basis of $30 \%$ market penetration, over 150 trillion Btu/yr could be saved.

The energy reductions are the result of eliminating the operation of crude and vacuum units and lowering pressure and hydrogen requirements for downstream processing. This preliminary study indicates that yields of transportation fuels with lower sulfur contents can be maximized; this benefit will be of increasing importance to refiners as they are required to meet more stringent low-sulfur fuel standards.

Table 4.1 Estimates of Fuels and Utility Comparison for Crude Distillation vs. Thermal Cracking

\begin{tabular}{|lcc|}
\hline \multicolumn{1}{|c}{ Parameter } & Crude Distillation & Thermal Cracking \\
\hline Energy Use & & \\
Power & 29,232 & 24,088 \\
Fuels/Steam & 189,660 & 140,579 \\
Hydrogen Feedstock & 84,221 & 69,180 \\
Total Energy Use & 303,113 & 233,847 \\
& & \\
Produced Energy & & 216,000 \\
Fuel Gas & 222,000 & 432,000 \\
Coke Burn & 432,000 & \\
& & $(414,153)$ \\
Net Energy & $(350,887)$ & \\
\hline
\end{tabular}

Notes:

- "Gross" electricity (includes energy lost during generation and transmission of electricity) is based on a conversion factor of $10,500 \mathrm{Btu} / \mathrm{kWh}$.

- Fuel gas is estimated in FOE (fuel oil equivalents), equal to 6 million Btu/bbl fuel oil. Steam value is estimated at 1,100 Btu/lb of steam.

Table 4.2 Reduction in Carbon Emissions and Energy Use: Thermal Cracking vs. Crude Distillation

\begin{tabular}{|lccc|}
\hline \multicolumn{1}{c}{ Item } & $\mathbf{2 0 1 0}$ & $\mathbf{2 0 1 5}$ & $\mathbf{2 0 2 0}$ \\
\hline Energy (trillion Btu) & 151.5 & 180.1 & 234.3 \\
Carbon Emissions (MMTCE) & 3.3 & 4.0 & 5.2 \\
\hline
\end{tabular}

Notes: Assumes $30 \%$ of crude and vacuum towers are replaced with thermal crackers by $2010,45 \%$ by 2020 . 


\subsection{Biodesulfurization}

The amount of sulfur present in marketed gasoline and other fuels is regulated under the Clean Air Act Amendments of 1990 to reduce the levels of sulfur dioxide (an acid rain precursor) that are released to the environment. Refiners are currently meeting the requirements of 200-ppm sulfur without excessive capital expenditures through hydrodesulfurization (HDS)/hydrotreatment processes. However, to meet the much lower levels that will be required early in the next century (expected to be in the range of $0-150 \mathrm{ppm}$ ), costly investments in new capital equipment will be needed unless alternative methods or new HDS catalysts are developed.

Biodesulfurization (BDS) appears to be an especially attractive alternative to HDS since it has potentially lower capital and operating costs. BDS utilizes a biological agent (or catalyst) for the removal of sulfur, rather than the conventional cobalt or molybdenum catalysts commonly employed for HDS. The use of the biological agent results in lower temperatures and atmospheric pressure and eliminates the need for hydrogen as a feed and combustion of fuel gas [52-53]. A flow diagram for the EBS-BDS process is shown in Figure 4.3; it is based on the information provided in [54].

The energy requirements for HDS vs. BDS of diesel fuel were evaluated and compared on the basis of data available from the literature for conventional HDS $[48,49]$ and a recent study by Energy BioSystems. The diesel fuel was assumed to have an initial sulfur content of $0.2 \%$, which was reduced to $0.005 \%$ after treatment by HDS or BDS. For this analysis, it was assumed

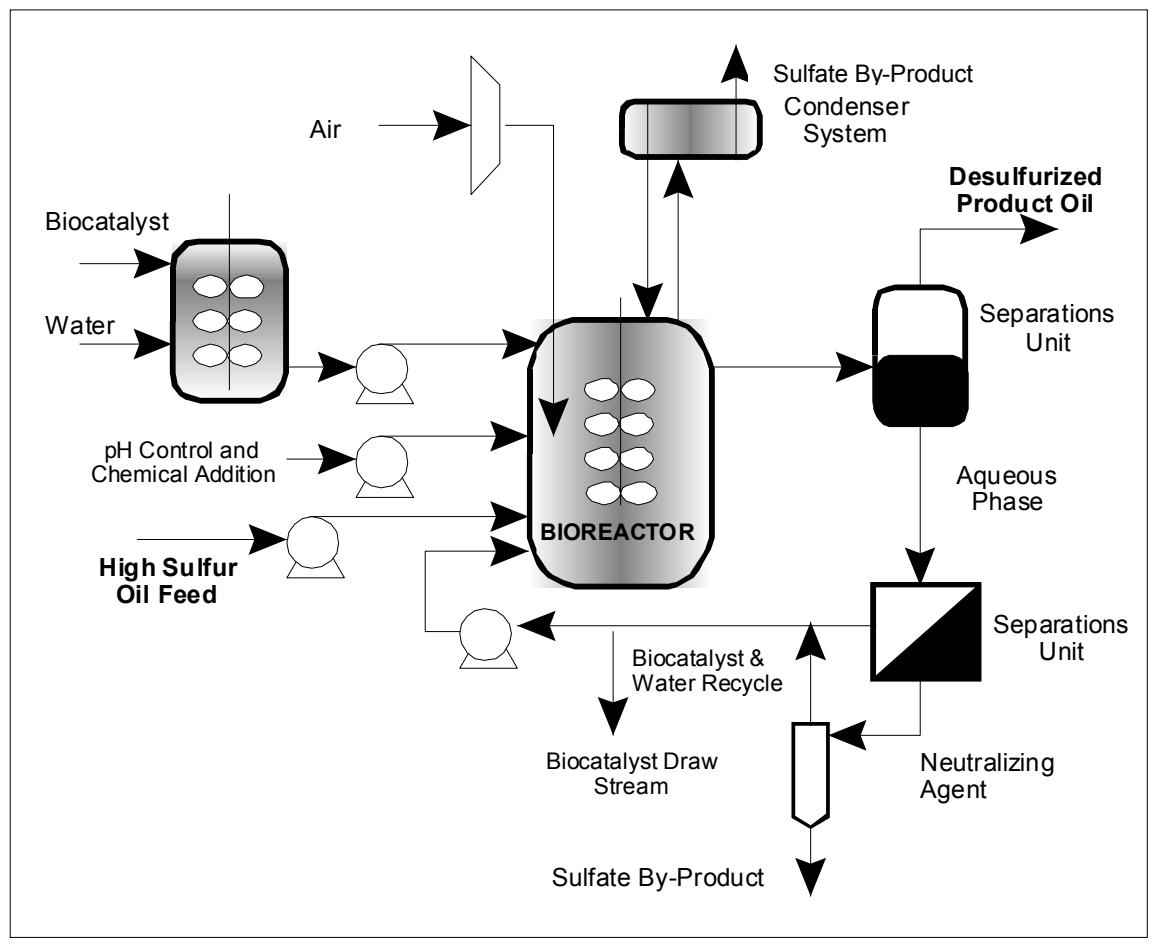

Figure 4.3 Biodesulfurization Flow Diagram 
that the hydrogen needed for HDS (500 scf/bbl [standard cubic feet/barrel]) was produced by steam reforming of methane. Methane requirements for this purpose were assumed to be $251 \mathrm{Btu} / \mathrm{scf}$ of hydrogen. Methane was also assumed to be the sole fuel used for production of steam and other process heat. For calculating $\mathrm{CO}_{2}$ emissions, electricity consumption was based on the energy mix used by the national grid (coal, methane, nuclear, and small amounts of fuel oil and renewables). Losses incurred during the generation and transmission of electricity were not considered. For the BDS process, ethanol is required to drive the reaction and was accounted for in the energy calculations. $\mathrm{CO}_{2}$ produced by the bacteria from respiration and biodesulfurization was also included in $\mathrm{CO}_{2}$ emissions.

A critical factor impacting a comparative energy-use analysis is the quantity of $\mathrm{H}_{2}$ consumed per barrel of feedstock processed in the HDS unit. This value is a function of the feedstock, catalyst, and operating parameters. On the basis of a review of the data presented in $[48,49]$, a value of $\mathrm{H}_{2}$ consumption of $500 \mathrm{scf} / \mathrm{bbl}$ was selected. The estimated savings presented, therefore, should be construed only as indicative of the level of energy savings $\left(\mathrm{CO}_{2}\right.$ reductions $)$ that may be realized.

Potential energy savings and the associated reduction in carbon emissions derived from this study are shown in Table 4.3. These values were calculated on the basis of using the BDS process for desulfurization of about $50 \%$ of diesel fuel having a sulfur content greater than $0.05 \%$. This market was estimated by using refinery output of diesel fuels in 1996 and applying an annual growth rate of less than $1 \%$ applied through the out-years. The resulting impacts are significant - energy savings of about 69 trillion Btu annually by 2010 and reduction in carbon emissions of over 1 MMTCE.

Table 4.3 Comparison of Energy Requirements and Carbon Emissions: HDS vs. BDS

\begin{tabular}{|cccccc|}
\hline Feed & $\begin{array}{c}\text { HDS } \\
\left(\mathbf{1 0}^{\mathbf{3}} \mathbf{B t u} / \mathbf{b b l}\right)\end{array}$ & $\begin{array}{c}\text { BDS } \\
\left(\mathbf{1 0}^{\mathbf{3}} \mathbf{B t u} / \mathbf{b b l}\right)\end{array}$ & $\begin{array}{c}\text { Reduction in } \\
\text { Consumption } \\
\left(\mathbf{1 0}^{\mathbf{3}} \mathbf{B t u} / \mathbf{b b l}\right)\end{array}$ & $\begin{array}{c}\text { Annual Energy } \\
\text { Reduction in } \mathbf{2 0 1 0} \\
\left(\mathbf{1 0 ^ { 1 2 }} \mathbf{B t u}\right)\end{array}$ & $\begin{array}{c}\text { Reduction in } \\
\text { Carbon Emissions } \\
\text { in 2010 (MMTCE) }\end{array}$ \\
\hline Diesel Fuel & 356.0 & 56.0 & 300.0 & 68.8 & 1.15 \\
\hline
\end{tabular}

Note: Assumes a maximum $20 \%$ penetration of U.S. markets for desulfurization of fluidized-catalytic-cracked gasoline, diesel products, and desulfurization of crude oil.

There is also a major potential to use the BDS technology to desulfurize crude oil. Although technically feasible, HDS is not usually economical for this application. In the current refinery configuration, sulfur is always removed downstream of the crude distillation unit. With the decreasing quality of available crude oil becoming more and more an issue for U.S. refiners, it is conceivable that BDS of crude oil, if proven feasible, could have as large or greater impact than the combined impacts of BDS of diesel fuels and FCC of gasoline.

\subsection{Development of Improved Catalysts}

The development of improved catalysts for key energy-intensive processes that can improve product yields/selection or that have lower energies of activation is a research direction that can 
lead to substantive improvements in energy use and, hence, $\mathrm{CO}_{2}$ reduction. Examples of process areas that can benefit from improved catalysts include hydroprocessing and catalytic cracking.

In hydroprocessing, much energy is utilized in heating up heavy oils and resids to temperatures at which catalyst activity is optimal. Additional energy is expended in the compression of hydrogen to pressures of up to 2,000 psi. Improved catalysts (capable of functioning at lower temperatures and pressures) could reduce the energy used by decreasing the reaction temperature of this process. Currently, the hydrotreating reactions take place at 660 $750^{\circ} \mathrm{F}$. Work on various catalysts and catalysts combined with various solvents has shown that significant hydrotreating activity can be attained at $570^{\circ} \mathrm{F}$. In addition, the hydrogen selectivity of some of these catalysts is equal or superior to that of commercial catalysts. Improved hydrogen selectivity would reduce hydrogen consumption per barrel of oil converted, and so less hydrogen would need to be generated and compressed.

Energy usage could be improved for catalytic cracking in terms of product selectivity. Cracking catalysts are extremely efficient at converting "good" gas oils to gasoline and distillate. However, when significant fractions of resid (and the metals that come along with these resids) are used as FCC feeds, the selectivity (in terms of gasoline yield) drops dramatically. This gasoline loss comes at the expense of increased coke and dry gas yield. Catalyst coolers are therefore required to keep the temperature of the catalyst bed down (which comes from increased coke burn), and higher compressor capacity is required to handle the increased dry gas yield. If catalysts were designed to more properly handle higher amounts of heavy oils without the detrimental effects outlined above, then more resid could be handled in the highly efficient fluidized catalytic cracker, thereby decreasing the utilization of the less-efficient hydrotreaters. 


\section{Section 5 \\ Showcase Demonstration Program for Improving Refinery Efficiency}

In 1996, the DOE Office of Industrial Technologies (OIT), in collaboration with a consortium of small refining service providers headed by Planetec and ANL, entered into an agreement with the management of the Colorado Refinery Company to undertake a study to define a comprehensive package of process efficiency improvements as a showcase demonstration program. The goal of this program is to show the potential economic and environmental benefits of implementing a package of technologies that would reduce energy use and, in turn, gaseous emissions (such as greenhouse gases), as well as other criteria pollutants.

Initially, a utility system and energy/mass balance was completed to establish a baseline. Thereafter, a wide spectrum of efficiency improvement studies was undertaken to identify the most promising opportunities (e.g., process integration of fuel/gas systems; energy management of electrical/chemical fuel sources; steam system analyses; waste-heat-driven, high-lift heat pump applications; cooling enhancements; high-efficiency motors; product yield improvements; cogeneration system impacts). Thirty-three utility and efficiency improvement measures, many of which were described in this report, were identified and integrated into a four-phase master plan that could be implemented over 3-5 yr. Thirteen relatively low-cost efficiency improvement measures (e.g., installation of inserts in selected heat-exchanger tubes to improve heat transfer [thermal efficiency], installation of a vacuum crude unit heater, installation of enhanced insulation in selected components) were completed in Phase I. These improvements had a payback of $0.66 \mathrm{yr}$.

The WHAARP, described earlier, which was cost-shared by DOE, was installed in Phase II. The partial use of the system has led to the recovery of $\approx 180 \mathrm{bbl}$ of petroleum products/day since initiation of operation in August 1997. Simple payback for this first-of-a-kind installation of a waste-heat-driven chiller is $1.5 \mathrm{yr}$. Phases III and IV each comprise nine efficiency improvement measures; if and when they are implemented, they would have simple paybacks of 2.58 and $2.04 \mathrm{yr}$, respectively. The overall payback for the four-phase master plan is $2.3 \mathrm{yr}$.

The impact of the complete implementation of the first three phases of the master plan on the refinery's energy intensive index (EII), energy consumed per barrel of oil produced, and emissions are substantial, as shown in Figure 5.1 and Table 5.1. As indicated in Figure 5.1, the EII (normalized to the year 1994) will drop by $\approx 25 \%$. The improved energy-use efficiency that would be achieved during Phases I-III could reduce on- and off-site refinery emissions by 30,100 tons/yr. The dramatic improvements achievable need to be placed in perspective; the refinery is of moderate complexity (complexity index $=6.75$ ) and has a relatively high EII. Numerous opportunities for improving efficiency that existed in the refinery may not be available in a large heat-integrated complex refinery. Each refinery is unique, and therefore the opportunities in each will differ. 


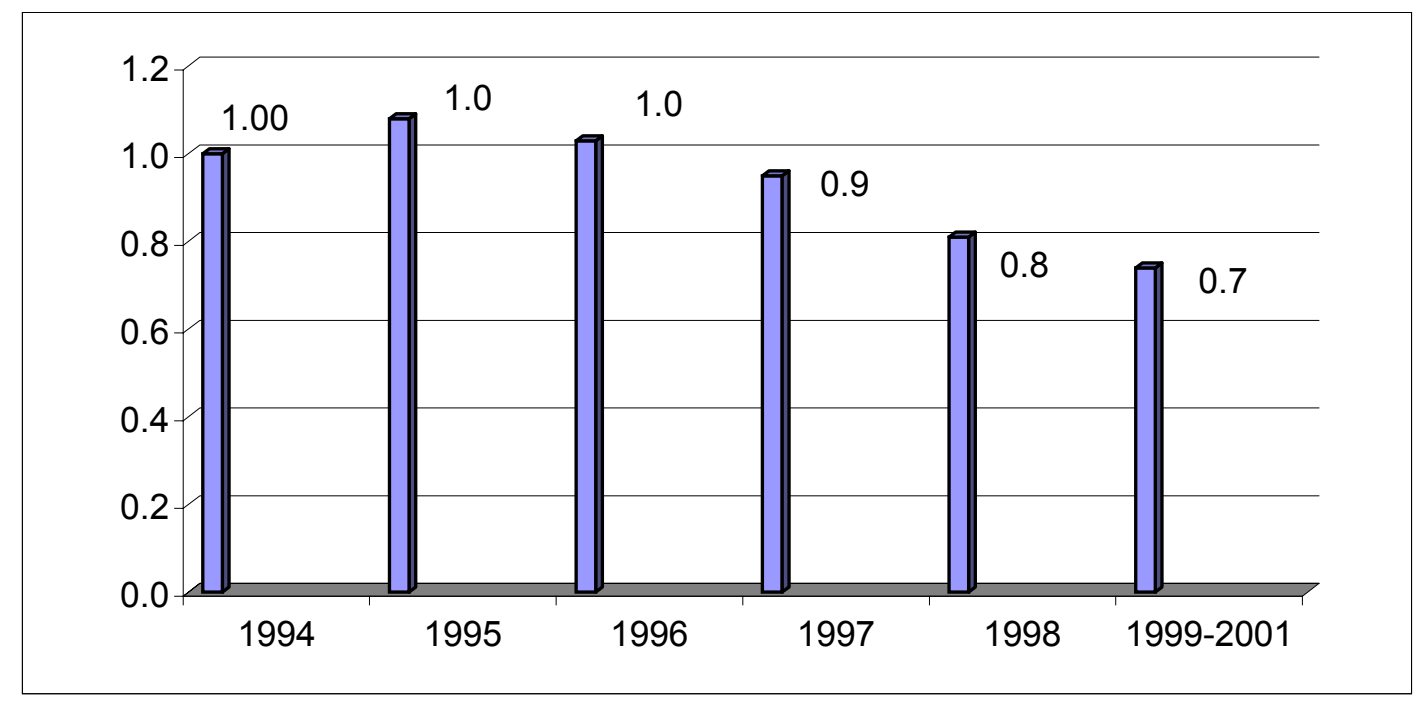

Figure 5.1 Projected Energy Intensity for the Denver Refinery

Table 5.1 Reduced Emissions from Implementation of the Master Plan on Refining

\begin{tabular}{|c|c|c|c|c|c|c|}
\hline \multirow{2}{*}{$\begin{array}{c}\text { Emission } \\
\text { (tons/yr) }\end{array}$} & \multirow{2}{*}{$\begin{array}{c}\begin{array}{c}\text { Phase I } \\
\text { Reduction } \\
\text { (tons/yr) }\end{array} \\
\text { On-Site } \\
\end{array}$} & \multicolumn{2}{|c|}{$\begin{array}{l}\text { Phase II Reduction } \\
\text { (tons/yr) }\end{array}$} & \multicolumn{2}{|c|}{$\begin{array}{c}\text { Phase III Reduction } \\
\text { (tons/yr) }\end{array}$} & \multirow{2}{*}{$\begin{array}{c}\text { Total } \\
\text { Reduction } \\
\text { (tons/yr) }\end{array}$} \\
\hline & & On-Site & Off-Site & On-Site & Off-Site & \\
\hline $\mathrm{CO}$ & -1.4 & -3.5 & & -11.3 & & -27.4 \\
\hline $\mathrm{NO}_{x}$ & -5.5 & -0.6 & -12.1 & -25.9 & -9.3 & -79.3 \\
\hline $\mathrm{SO}_{2}$ & -0.03 & & -15.7 & 15.7 & -12.0 & 3.7 \\
\hline PM10 & -0.6 & -0.02 & -0.8 & -4.5 & -0.6 & -11.1 \\
\hline VOC & -0.2 & -0.5 & & -252.1 & & -505.0 \\
\hline $\mathrm{CO}_{2}$ & $-2,469.9$ & -179.1 & $-4,16.0$ & $-20,019.4$ & $-3,071.3$ & $-49,775.0$ \\
\hline
\end{tabular}




\section{Section 6 Conclusions}

The refining industry is a major source of $\mathrm{CO}_{2}$ emissions in the industrial sector and therefore can expect to face increasing pressures to reduce its levels of greenhouse gas emissions. The energy used in refining is affected by market dictates, crude quality, and environmental regulations. While the industry is technologically advanced and relatively efficient, additional opportunities undoubtedly exist to further reduce energy usage and $\mathrm{CO}_{2}$ emissions. The opportunities will vary from refinery to refinery and will have to be economically viable and compatible with each refiner's strategic plans.

In the near term, significant opportunities exist that, if they can be justified from either an economic and/or environmental stewardship vantage point, can lead to energy use and $\mathrm{CO}_{2}$ reduction of $3-7 \%$. In the mid- to long term, the potential reductions that may be achievable by adopting selected advanced technologies appear to be substantial, as summarized in Table 6.1. In light of the many factors involved, a target reduction of 15-20\% in energy use and $\mathrm{CO}_{2}$ emissions from the refining sector does not appear to be unreasonable, assuming a favorable investment climate. This projection must immediately be tempered by the probability that more stringent regulations will likely be imposed on the industry to reduce sulfur levels to very low levels in gasoline and diesel fuels. Such reductions are intended to help the advanced, moreefficient transportation vehicles that will be introduced into the marketplace in the next decade achieve very low mandated emissions levels (i.e., particulate matter and $\mathrm{NO}_{\mathrm{x}}$ ). Energy usage and carbon emission reductions achievable would likely suffer significantly.

Table 6.1 Reduction in Energy Use and Carbon Emissions Possible through Adoption of Selected Advanced Technologies in Petroleum Refining

\begin{tabular}{|lcc|}
\hline \multicolumn{1}{|c|}{ Technology } & $\begin{array}{c}\text { Energy Savings } \\
\left(\mathbf{1 0}^{\mathbf{1 2}} \mathbf{~ B t u}\right)\end{array}$ & $\begin{array}{c}\text { Carbon Reductions } \\
\text { (MMTCE) }\end{array}$ \\
\hline Thermal Cracking vs. Crude Distillation & 151.5 & 3.3 \\
Optimized Fluidized Catalytic Cracker & 36.0 & 0.67 \\
Solid Acid vs. Liquid Acid Catalyst Alkylation & 2.6 & 0.04 \\
Biodesulfurization of Diesel Fuel & 68.8 & 1.15 \\
Combustion Efficiency Improvements & 229.9 & 4.3 \\
Advanced Turbine Systems/Cogeneration & 76.7 & 1.42 \\
Improved Distillation Processes & 92.2 & 1.7 \\
Waste-Heat-Driven Chillers - Condensers, Atmospheric and & 23.1 & 0.39 \\
Vacuum Columns (25 ${ }^{\circ} \mathrm{F}$ change in water temperature only) & & 1.03 \\
Fouling Mitigation & 55.12 & 14.22 \\
TOTALS & 747.54 & \\
\hline
\end{tabular}




\section{Section 7 References}

[1] “Kyoto Protocol on Global Climate Change," 1998, Kyoto, Japan, Nov.

[2] Intergovernmental Panel on Climate Change, 1995, Climate Change 1995, Cambridge University Press.

[3] Interlaboratory Working Group, 1997, "Scenarios of U.S. Carbon Reductions: Potential Impacts of Energy Technologies by 2010 and Beyond," Lawrence Berkeley National Laboratory, Berkeley, Calif., and Oak Ridge National Laboratory, Oak Ridge, Tenn., LBNL-40533 and ORNL 444, Sept.

[4] U.S. Department of Energy, Energy Information Administration, 1998, Monthly Energy Review, DOE/EIA-0035, April.

[5] "Energy and Environmental Profile of the United States Petroleum Refining Industry," 1998, draft report prepared by Energetics, Inc., Columbia, Md., for the U.S. Department of Energy, July.

[6] U.S. Department of Energy, Energy Information Administration, 1997, “Technology Opportunities to Reduce U.S. Greenhouse Gas Emissions," prepared by National Laboratory Directors, U.S. Government Printing Office, Washington, D.C., Nov. 13.

[7] U.S. Department of Energy, 1994, Emission of Greenhouse Gases in the United States, 1987-1992, U.S. Government Printing Office, Washington, D.C.

[8] Haynes, V.O., 1976, "Energy Use in Petroleum Refineries," Oak Ridge National Laboratory report ORNL/TM-5433, Oak Ridge, Tenn., Sept.

[9] U.S. Department of Energy, 1990, Industry Profiles - Final Report: Energy Profiles for U.S. Industry, Office of Industrial Technologies, U.S. Government Printing Office, Washington, D.C.

[10] Ladeur, P., and H. Bijwaard, 1993, "Shell Plans \$2.2 Billion Renovation of Dutch Refinery,” Oil \& Gas Journal, April.

[11] Robertson, J., 1997, “Potential Energy Improvements — Emphasis on Refining,” personal communication to Argonne National Laboratory, March.

[12] “Ongoing Study of Energy Efficiency Improvements at a Low Complexity Refinery," 1977, unpublished information, Argonne National Laboratory. 
13] Brant, B., et al., 1998, "New Waste-Heat Refrigeration Unit Cuts Flaring, Reduces Pollution," Oil \& Gas Journal, May 18.

[14] Humphrey, J.L., and G.E. Keller II, 1997, Separation Process Technology, McGraw-Hill, New York.

[15] Cadman, T.W., 1988, “CAAPS: Computer-Aided Design for Process Systems," ENSCI, Inc., POB 513, North College Park Station, College Park, Md.

[16] Chang, S.L., et al., 1998, "Interactions of Multi-Phase Hydrodynamics, Droplet Evaporation, and Chemical Kinetics in FCC Riser Reactors," HTD-Vol. 357, Proceedings of the ASME Heat Transfer Division 1:261-269, the 7th AIAA/ASME Joint Thermophysics and Heat Transfer Conference, Albuquerque, N.M., June 15-17.

[17] Barthod, D., M. DelPozo, and C. Mirgain, 1999, “CFD-Aided Design Improves FCC Performance," Oil \& Gas Journal, April 5.

[18] Theologos, K.N., et al., 1997, "Simulation and Design of Fluid Catalytic-Cracking RiserType Reactors," AIChE Journal, 43(2), Feb.

[19] CRADA-protected data from Chevron and UOP.

[20] OIT Benefits Analysis, performed by Energetics, Inc., Columbia, Md., for the U.S. Department of Energy. Energy and economic analysis of an optimized fluid catalytic cracker, based on data from Argonne National Laboratory, Chevron, and UOP, 1996.

[21] U.S. Department of Energy, 1990, Industry Profiles-Final Report: Energy Profiles for U.S. Industry, Office of Industrial Technologies, U.S. Government Printing Office, Washington, D.C.

[22] Rivero, R., et al., 1989, "Energy Analysis of a Crude Oil Atmospheric Distillation Unit," pp. 506-510 in Proceedings of the International Symposium on Thermodynamic Analysis and Improvement of Energy Systems TAIES ‘89, International Academy Publishers, Beijing.

[23] Levine, M.D., et al., 1995, "Efficient Use of Energy Utilizing High-Technology Assessment of Energy Use in Industry and Buildings," World Energy Council Report, London, Kogan Page Ltd., Sept.

[24] U.S. Department of Energy, 1978, Energy Conservation in Distillation, DOE/CS/4431-T2, Washington, D.C.

[25] Flores, J., et al., 1984, unpublished information, July.

[26] Robertson, J.L., 1990, Energy and the Environment in the 21st Century, MIT Press, Cambridge, Mass. 
[27] Tripathi, N., and D. Shukla, 1991, "Environmentally Responsible Energy Management," Hydrocarbon Processing, 70(10), Oct.

[28] Samdani, R., and S. Moore, 1993, "Pinch Technology: Doing More with Less," Chem. Eng. 100(7), July.

[29] Hall, T.P., G. Ognisty, and A.H. Northup, 1995, "Use Process Integration to Improve FCV/VRU (Vapor Recovery Unit)," Hydrocarbon Processing, 74(4), April.

[30] Fleming, P., A.W. Sloley, and S.W. Golden, 1993, "Heat Integrating Catalytic Cracking Unit Fractionation Systems," 1993 AIChE Annual Meeting, St. Louis, Mo., Nov. 7-12, Preprint No. 195B.

[31] Rossiter, W., H.D. Spriggs, and H. Klee, 1991, "Reduce Process Emissions at the Source Using Pinch Analysis,” 1991 AIChE Summer National Meeting, Pittsburgh, Penn., Aug. 18-21, 1991, Preprint No. 949.

[32] Sunden, R., 1996, "Analysis of the Heat Recovery in Two Crude Distillation Units," Heat Recovery Systems and CHP, 5(8):483-488.

[33] Clayton, W., 1994, Cost Reduction in an Oil Refinery Identified by a Process Integration Study at Gulf Oil Refining, Ltd., Harwell, UK:ETSU.

[34] Leach, S.H., and J.L. Holuska, 1981, Fouling of Refinery Heat Transfer Equipment, Hemisphere Publishing Co., Washington, D.C., pp. 619-643.

[35] Ross, J.L., and P.A. Minton, 1996, "FCC Performance Revamp and Their Impact on Future Refinery Operations," The European Refining Technology Conference, London, England, Oct. 28-30.

[36] Panchal, C.B., and E.-P. HuangFu, 1998, "Effects of Mitigating Fouling on the Energy Efficiency of Crude-Oil Distillation,” AIChE Spring Meeting, New Orleans, La., March.

[37] Quintana, M., et al., 1996, "The Gasification Solution - Heavy End Optimization," The European Refining Technology Conference, London, England, Oct. 28-30.

[38] Dharmadhikari, S., 1997, "Consider Trigeneration Techniques for Process Plants," Hydrocarbon Processing, July.

[39] U.S. Department of Energy, 1994, Manufacturing Energy Consumption Survey, 1994, Energy Information Administration, U.S. Government Printing Office, Washington, D.C.

[40] Reed, J., 1997, "Energy Analysis of Potential Impact of Industrial ATS (2000-2010)," prepared by Energetics, Inc., Columbia, Md., for the U.S. Department of Energy, June. 
41] "Basis for Remaining Cogeneration Potential in the Industrial Sector," 1997, prepared by On-Site Energy Corporation for the U.S. Department of Energy, May.

[42] Pellegrino, P., 1993, "Prototype Technology Characterization: Advanced Turbine System," prepared by Energetics, Inc., Columbia, Md., for the U.S. Department of Energy, Nov.

[43] Rao, P., and S.R. Vatcha, 1996, "Solid-Acid Alkylation Process Development Is At Crucial Stage," Oil \& Gas Journal, Sept.

[44] Zhang, Y., et al. (assigned to UOP), 1996, U.S. Patent No. 5,489,732, Feb.

[45] "Energy and Environmental Profile of the Petroleum Refining Industry," 1997, draft report, prepared by Energetics, Inc., Columbia, Md., for the U.S. Department of Energy, Dec.

[46] Dawson, F.N., et al., 1995, Heavy Crude Oil Processing Via Fluidized Bed Cracking and Hydrogeneration - Final Report, CRADA No. C/ANL-9301001, Sept.

[47] Bartholic, D.B., et al., 1986, "Petroleum Refinery of the Future," presented at the Japan Petroleum Institute, Tokyo, Oct. 27.

[48] Suchanek, A.J., and A.S. Moore, 1986, "Modern Residue by ART (Asphalt Residual Treatment)," National Petroleum Refiners Association Meeting, March 23-25, Los Angeles, Calif., AM-86-15.

[49] Dawson, F.N., 1995, "Heavy Oil Upgrading Via Fluidized Bed and Hydrogenation Processing," presented at the 1995 National Petroleum Refiners Association Annual Meeting, San Francisco, Calif., March (AM-95-15).

[50] Inomata, M., et al., 1997, "Engineering Firm Has Designed Refinery of the Future," Oil \& Gas Journal, April 28.

[51] SFA Pacific, Inc., 1993, Upgrading Heavy Crude Oils and Residues to Transportation Fuels: Technology, Economics, and Outlook: Phase IV, Mountain View, Calif.

[52] Data provided to the Interagency Environmental Technology Office, Washington, D.C., by Energy BioSystems Corporation, The Woodlands, Texas, Oct. 1995.

[53] Linquist, L., and M. Pacheco, 1999, "Enzyme-Based Diesel Desulfurization Process Offers Energy, $\mathrm{CO}_{2}$ Advantages," Oil \& Gas Journal, Feb. 22.

[54] U.S. Department of Energy, 1999, Petroleum Project Fact Sheet on Gasoline Biodesulfurization, Office of Industrial Technologies, Washington, D.C., Jan. 